\title{
1 Brittle Deformation of Carbonated Peridotite - Insights from Listvenites of 2 the Samail Ophiolite (Oman Drilling Project Hole BT1B)
}

Manuel D. Menzel ${ }^{1 *}$, Janos L. Urai ${ }^{1,2}$, Juan Carlos de Obeso ${ }^{3}$, Alissa Kotowski ${ }^{4 \wedge}$, Craig E. Manning ${ }^{5}$, Peter B. Kelemen ${ }^{3}$, Michael Kettermann ${ }^{6}$, Ana P. Jesus ${ }^{2 \#, ~ Y u m i k o ~}$ Harigane $^{7}$, and the Oman Drilling Project Phase 1 Science Team

${ }^{1}$ Institute of Structural Geology, Tectonics and Geomechanics, RWTH Aachen University, Germany

${ }^{2}$ German University of Technology GUtech, Muscat, Oman

${ }^{3}$ Lamont-Doherty Earth Observatory, Columbia University, USA

${ }^{4}$ Department of Geological Sciences, Jackson School of Geosciences, University of Texas at Austin, Austin, TX USA

${ }^{5}$ University of California Los Angeles, USA

${ }^{6}$ Department of Geodynamics and Sedimentology, University of Vienna, Austria

${ }^{7}$ Institute of Geology and Geoinformation, Geological survey of Japan, National Institute of Advanced Industrial Science and Technology, Tsukuba 305-8567, Japan

$\wedge$ Now at Department of Earth and Planetary Sciences, McGill University, Montreal, Quebec, Canada

\# now at Instituto Dom Luiz (IDL), Faculdade de Ciências, Universidade de Lisboa, Lisboa, Portugal

*Corresponding author email: manuel.menzel@emr.rwth-aachen.de

\section{Key Points:}

- Abundant cataclasites overprint previously formed listvenite in the Oman Drilling Hole BT1B.

- Cataclasis was related to fluid flow, which caused Mg loss and/or Si enrichment, and local redistribution of $\mathrm{Cr}$.

- The multistage tectonic overprint after peridotite carbonation in the Oman ophiolite should be excluded when analysing early structures. 


\section{Abstract}

12 Hole BT1B of the Oman Drilling Project provides a continuous sampling from listvenite into 13 the metamorphic sole that preserves the deformation, hydration and carbonation processes of 14 oceanic mantle peridotite at the base of the Samail ophiolite, Oman. We present evidence of 15 multistage brittle deformation in listvenites and serpentinites based on field observations, 16 visual core logging and petrography. About 10 vol\% of listvenite and serpentinite in Hole 17 BT1B is composed of cataclasite bands. Cataclasites contain lithic clasts of listvenite with 18 spheroidal, zoned magnesite and quartz, and fragments of chalcedony-carbonate veins that 19 elsewhere crosscut listvenite - showing that cataclasis post-dates listvenite formation. 20 Locally the cataclasites are reworked and cut by thin, sharp faults, pointing to repeated 21 reactivation of brittle structures. SEM-EDS mapping shows that cataclasis was related to silica cementation and/or dissolution of carbonate. Dolomite veins crosscut cataclasites and breccias, suggesting that part of the Ca gain in BT1B is related to late fluids after listvenite formation. These results indicate a multistage tectonic overprint after peridotite carbonation and listvenite formation, which may be related to the tectonic history of the deformed continental margin under the ophiolite. These relatively late brittle structures should be excluded when trying to understand the carbonation of peridotite to listvenite. 


\section{Introduction}

The interaction of mantle rocks with aqueous fluids causes large amounts of volatiles to be stored in altered peridotite due to hydration (serpentinization) and carbonation reactions of olivine and pyroxene. These reactions are particular in that they produce very volatile-rich alteration products (up to $15 \mathrm{wt} \% \mathrm{H}_{2} \mathrm{O}$ or $35 \mathrm{wt} \% \mathrm{CO}_{2}$ in fully hydrated or carbonated peridotite, respectively), have comparatively fast reaction rates, and can pervasively transform large volumes of rock (Kelemen et al., 2011). Therefore, the alteration of Mg-bearing silicates in peridotite can have a substantial impact on the global geochemical cycling of volatiles (Alt et al., 2013; Beinlich et al., 2018). In particular, peridotites in the cold part of the mantle wedge of subduction zones may take up large amounts of water and carbon during serpentinization and carbonation reactions caused by C-bearing, aqueous subduction fluids derived from the slab (Hyndman and Peacock, 2003; Kelemen and Manning, 2015). The reaction characteristics of olivine and pyroxene alteration further make exposures of peridotites in ophiolites a promising target for strategies of carbon sequestration by mineral carbonation (Kelemen et al., 2018; Kelemen \& Matter, 2008; Paukert et al., 2012).

In the extreme, the interaction of peridotite with C-bearing fluid produces listvenite, a rock where all $\mathrm{Mg}$-bearing silicates are replaced by carbonate and quartz, and relict chromian spinel is partly transformed into chromian mica (fuchsite-muscovite solid solutions) (Halls and Zhao, 1995). Listvenites often are associated with talc-carbonate assemblages (soapstone) and carbonate-bearing serpentinites, which form at different fluid/rock ratios during the interaction of peridotite with C-bearing aqueous fluids (Beinlich et al., 2012; Hansen et al., 2005; Menzel et al., 2018). Because serpentinized peridotites have low Ca contents, carbonates in listvenites are typically magnesite and minor dolomite. C-bearing fluids are commonly interpreted to be derived from underlying carbonate-bearing metasediment. Locally, listvenites can be associated with birbirite - silicified serpentinite consisting mostly of quartz with only minor carbonate and relict Cr-spinel (Akbulut et al., 2006; Lacinska \& Styles, 2013; Nasir et al, 2007; Stanger, 1985) - or magnesite-fuchsite rocks that contain only traces of quartz (Menzel et al., 2018). Thermodynamic models suggest that both birbirites and magnesite-rich rocks can be the result of extended fluid-rock interaction to high water/rock ratios after listvenite formation at different temperatures (Klein and Garrido, 2011).

A very interesting and controversial aspect of the hydration and carbonation of peridotite is how these reactions can go to completion. Because solid mass is increased by addition of $\mathrm{H}_{2} \mathrm{O}, \mathrm{CO}_{2}$, and the hydrated and carbonated solid products have lower densities than the solid reactants, reactions increase the solid volume. Fluid-rock reactions that increase the solid volume may fill porosity, reduce permeability, and produce reaction rims to stop the reaction (Andreani et al., 2009; Farough et al., 2016; Godard et al., 2013; Oelkers et al., 2018; van Noort et al., 2017). Accordingly, observations in experiments of carbonation of natural peridotite by several groups (Andreani et al. 2009; Godard et al. 2013; Hövelmann et al., 2013; van Noort et al. 2017) showed decreasing permeability, suggesting that the carbonation reaction was self-limiting in these experiments. However, in nature, replacement of peridotite by carbonates can proceed to completion, as shown by listvenites. A key to how this process goes to completion may be hierarchical fracture networks, where the crystallization pressure creates local gradients in differential stress and drives fractures, which in turn increase permeability and reactive surface area (e.g., Malthe-Sørenssen et al., 2006; O'Hanley, 1992; Rudge et al., 2010; Ulven et al., 2014), as experimentally demonstrated for hydration of periclase (Zheng et al., 2018). On a larger scale, volume change may also cause differential stress and fracture, as proposed for olivine hydration by Macdonald and Fyfe (1985). 
Alternatively, anisotropic far field stress in tectonic deformation can lead to dilatancy and allow the reaction to go to completion.

A review by Kelemen and Hirth (2012) suggests that the crystallization pressure during carbonation of peridotite can be very large, and argues that this process can lead to a positive feedback due to cracking, allowing the reaction to go to completion. Phase field models suggest a positive feedback between reaction driven cracking and the local rate of peridotite hydration in hierarchical vein networks (Evans et al., 2020), a process that may also apply to carbonation reactions. Zhu et al. (2016) conducted a mineral carbonation experiment on olivine using synchrotron X-ray micro-tomography, which showed polygonal cracks propagating into the interior of the olivine aggregate. They infer that non-uniform volume expansion induced by the reactions generates polygonal cracking of the surfaces. In addition, the reaction products may be micro-to nano-porous, providing fluid pathways through the matrix, which may cause microstructural maintenance and enhancement of permeability via combined dissolution and precipitation processes (Malvoisin et al., 2020; Peuble et al., 2015; Tutolo et al., 2016). Studies propose that that dissolution etch pits along dislocations in olivine are preferentially filled with reaction products and form the nucleus for microcracks (Klein et al., 2015; Peuble et al., 2018; Plümper et al., 2012; Xing et al., 2018).

Brittle deformation may therefore play a key role in increasing the reactive surface area and maintaining or enhancing permeability. Accordingly, some engineering approaches to carbon sequestration by olivine carbonation achieve higher reaction rates by powdering of the reactant material (e.g. Li and Hitch, 2018, and references therein). However, in the absence of continued deformation during reaction, permeability reduction and deactivating silica reaction rims often prevail and inhibit complete carbonation (van Noort et al., 2017). Compaction and triaxial deformation experiments suggest mechanically enhanced dissolution rates during hydration and carbonation of olivine (Lisabeth et al., 2017). In natural reservoir and crustal conditions, mechanically enhanced reaction rates are likely to occur in brittle fault zones that are characterized by high permeability and renewal of reactive surfaces due to faulting and cataclasis. Listvenites are indeed often related to major thrust faults and show evidence of brittle deformation such as tectonic breccias and veins (Escayola et al., 2009; Menzel et al., 2018; Qiu and Zhu, 2018).

The Samail ophiolite in Oman includes large surface exposures of variably hydrated and carbonated mantle rocks - an ideal place to study the interaction between rock deformation and peridotite alteration. Listvenites occur along the basal thrust of the ophiolite in the Samail massif (Nasir et al., 2007; Wilde et al., 2002). Previous field, geochemical and microstructural studies of the Oman listvenites (Falk and Kelemen, 2015; Kelemen et al., 2011; Nasir et al., 2007; Rajendran et al., 2013; Stanger 1985) did not address how the transformation of peridotite to listvenite could proceed at a large scale. In parts this is due to the outcrop conditions with thick weathering crusts and abundant fracturing, which also hindered a systematic study of deformation structures. Hole BT1B of the Oman Drilling Project was drilled for this reason, to acquire a fresh core from a continuous section from listvenite into the metamorphic sole that would allow systematic (micro)structural and geochemical logging of the carbonation reaction processes. The tabular nature of listvenite bands in partially serpentinized peridotite at Oman Drilling Site BT1, parallel to the gently dipping basal fault of the ophiolite, suggests that large scale, imbricate faults may have played a role in guiding the $\mathrm{CO}_{2}$-bearing fluids that formed listvenite. 
Here we present evidence of multistage brittle deformation in listvenites and serpentinites based on field observations, visual core inspection and petrography, using the unique sample set from Hole BT1B. The aim of this contribution is to study whether widespread cataclasites in the Oman listvenites are coeval with carbonation and are examples of mechanically enhanced reaction rates, or whether they post-date listvenite formation. In order to evaluate the possibility of post-obduction tectonic overprint for cataclasite formation in listvenite, we further compare the cataclasite and fault microstructures and conditions with postemplacement structures in the underlying carbonate-bearing units.

\section{Geological setting}

\subsection{Tectonic evolution of the Oman mountains}

The Samail ophiolite (Fig. 1a) exposes a relatively intact sequence of obducted oceanic crust (4-8 km thick; Nicolas et al., 1996) and mantle (9-12 km thick in the Wadi Tayin massif; Hanghøj et al. 2010; Hopson et al., 1981) formed during the Cenomanian (96.5 - 95.5 Ma; Rioux et al. (2013)) at a fast-spreading mid-ocean ridge or a supra-subduction zone spreading center (Coleman, 1981; Glennie et al., 1974; Searle and Cox, 1999). Intra-oceanic subduction of oceanic crust and sediment slices led to the formation of a high grade metamorphic sole beginning at about the same time as ophiolite formation (Hacker et al., 1996; Rioux et al. 2013) or up to $10 \mathrm{Ma}$ earlier (Guilmette et al. 2018; Soret et al., 2020). The sole records amphibolite to granulite facies peak metamorphic conditions $\left(530-850^{\circ} \mathrm{C}, 0.5-1.0 \mathrm{GPa}\right)$ and was exhumed along with peridotite at the basal thrust during ophiolite obduction (Cowan et al., 2014; Ghent and Stout, 1981; Hacker and Mosenfelder, 1996; Soret et al., 2017). The emplacement of the Samail ophiolite occurred by obduction onto allochthonous distal sediments (the Hawasina formation) in the first, intra-oceanic subduction stage, and subsequent top-to-S thrusting of both ophiolitic and allochthonous sediment nappes onto the thick autochthonous sediments of the Mesozoic passive margin of the Arabian plate (e.g. Searle and Cox, 1999). The Jebel Akhdar and Saih Hatat anticlinoria, exposed in peaks up to $3000 \mathrm{~m}$ high in the Al Hajar mountain range, form large-scale tectonic windows that permit the reconstruction of post-obduction tectonics that affected the continental carbonate platform due to the emplacement of the Hawasina and ophiolite nappes (Fig. 1a). Partial subduction and burial of the passive margin below the ophiolite nappe caused heating to different peak metamorphic conditions from $450-550{ }^{\circ} \mathrm{C}, 2.0-2.4 \mathrm{GPa}$ in eclogite of the deepest As Sifah complex NE of the Saih Hatat dome, to $280-360{ }^{\circ} \mathrm{C},<0.5-1.0 \mathrm{GPa}$ in the NW Saih Hatat (Agard et al., 2010; Miller et al., 1999; Saddiqi et al., 2006; Searle et al., 1994), and $300-360$ ${ }^{\circ} \mathrm{C}, 0.28-0.34 \mathrm{GPa}$ (lithostatic pressure) recorded in veins in carbonates of the Jebel Akhdar dome (Grobe et al., 2019). The burial caused fluid overpressure, and generation and migration of hydrocarbons, but little deformation in the carbonate platform (Grobe et al., 2016). This was followed by top-to-NNE ductile shear zones (Al-Wardi and Butler, 2007; Grobe et al., 2016), the deformation of earlier veins, and the formation of mylonitic marbles in the early Campanian ( $80-60 \mathrm{Ma})$ (Grobe et al., 2018). Normal and oblique-slip faults with horstgraben structures formed during Campanian to Maastrichtian times, after ophiolite obduction, with extension and dome exhumation (Grobe et al., 2018) accompained by sub-aerial erosion of the ophiolite followed by deposition of shallow marine carbonates (e.g. Nolan et al., 1990). This was followed by NE-SW shortening in the Miocene to Pliocene during large-scale folding of the Jebel Akhdar and Saih Hatat domes, which tilted the earlier structures (GomezRivas et al., 2014; Grobe et al., 2018). Widespread strike-slip faults postdate the large-scale 
167 folding (Gomez-Rivas et al., 2014; Grobe et al., 2018; Virgo et al., 2013). At the Northern

168 flank of Jebel Akhdar, final exhumation of the core of the anticlinorium occurred along

169 detachments (Grobe et al., 2018).

170
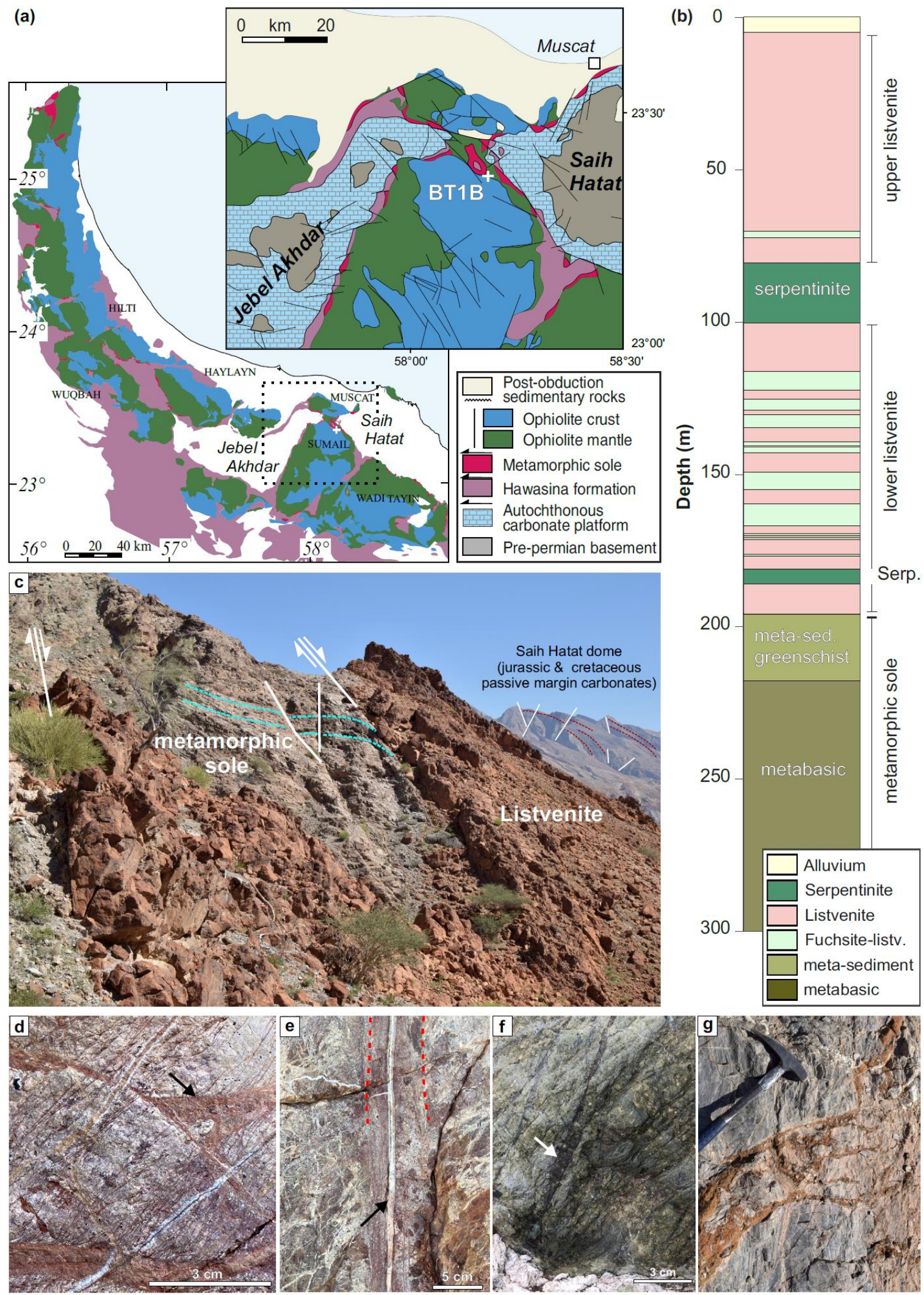
Fig. 1 (a) Lithological column of Hole BT1B; (b) Simplified geological overview map of Northern Oman (after Nicolas \& Boudier, 1995), and geology of the northern Samail massif (after Béchennec et al., 1992); (c) field view of the contact between listvenite and greenschists of the metamorphic sole looking east, with the Saih Hatat dome in the background; (d) red-stained cataclasite in listvenite, cut by white-yellowish dolomite veins; (e) listvenite cataclasite (marked red) reactivated by a sharp fault with quartz/carbonate vein (arrow); (f) black cataclasite in serpentinite; (h) red oxidized cataclasite in metasediments of the metamorphic sole.

172 Fluid inclusion thermobarometry of veins related to faulting in the Jebel Akhdar and Saih Hatat domes indicates that much of the tectonic evolution occurred under the overburden of the ophiolite (Grobe et al., 2019). Hence, the tectonic events observed in the carbonate platform probably affected the ophiolite as well, although this has not been studied in detail.

\subsection{Listvenites in the Samail massif and Hole BT1B}

Listvenites are common in the northern part of the Samail massif of the Samail ophiolite, Oman, where they form red- to orange-colored ridges that have a higher resistance to weathering than peridotite. Historically, these listvenites were also called the Amqat unit

180 (Glennie et al., 1974; Stanger, 1985). The listvenites occur along the basal thrust of the ophiolite where peridotite is in contact to the metamorphic sole (Nasir et al. 2007). The largest outcrops are in lenses along the transition from the Jebel Akhdar to the Saih Hatat domes of the Al Hajar mountain range (Falk \& Kelemen 2015; Stanger 1985; Villey et al., 1986; Wilde et al., 2002). Minor listvenite bodies also form tectonic blocks in shear zones within Hawasina meta-sediments and the metamorphic sole of the same area (Nasir et al., 2007).

186

187

188

189

190

191

192

193

194

195

196

197

198

199

200

201

202

203

204
The listvenites at Wadi Mansah are an outstanding natural example showing that peridotite carbonation reactions can go to completion on large scale (Falk and Kelemen, 2015). Where listvenite is in contact with serpentinized peridotite, the presence of intergrown antigorite + quartz \pm talc suggests temperatures of $80-130^{\circ} \mathrm{C}$, broadly consistent with clumped-isotope thermometry of carbonates $\left(45-245^{\circ} \mathrm{C}\right.$; Falk and Kelemen, 2015; Beinlich et al., 2020), and the presence of microcrystalline quartz (recrystallized from opal or chalcedony) (Streit et al., 2012). An internal $\mathrm{Rb}-\mathrm{Sr}$ isochron gives an age of $97 \pm 29 \mathrm{Ma}$ (Falk and Kelemen, 2015), in agreement with the age of emplacement of the ophiolite. Age corrected to $96 \mathrm{Ma},{ }^{87} \mathrm{Sr} /{ }^{86} \mathrm{Sr}$ values in the listvenite are consistent with those of the underlying Hawasina metasediments (Falk and Kelemen, 2015).

Hole BT1B of the Oman Drilling Project (International Continental Drilling Project Expedition 5057-4B) was drilled in Wadi Mansah (lat. 23.3643 ${ }^{\circ}$; lon. 58.1827 ${ }^{\circ}$ ) in March 2017, to sample a continuous, un-weathered section of listvenite, serpentinite and the metamorphic sole (Fig. 1a). The BT1B core has $100 \%$ recovery and includes about $200 \mathrm{~m}$ of listvenite intercalated with serpentinite (Fig. 1b). An upper section of $70 \mathrm{~m}$ of listvenite is followed by $20 \mathrm{~m}$ of carbonate-bearing serpentinite. A lower $80 \mathrm{~m}$ section of listvenite includes several domains rich in chromian mica (light green layers in Fig. 1b), and is underlain by $5 \mathrm{~m}$ of serpentinite. The lowermost $10 \mathrm{~m}$ of listvenite are separated from the metamorphic sole by $10 \mathrm{~cm}$ of black cataclasite and clay fault gouge, which forms part of the 
basal fault of the Samail ophiolite. Below the listvenites and fault gouge, the BT1B core contains $100 \mathrm{~m}$ of the metamorphic sole, comprising $30 \mathrm{~m}$ of metasedimentary rocks and $\sim 70$ $\mathrm{m}$ fine-grained metamafic rocks (Fig. 1b). All of the listvenite-serpentinite contacts are intact and gradational, and usually marked by domains of ophicarbonate.

While many calcite- and dolomite-bearing listvenites and birbirites (silicified serpentinite) in the northern Samail massif have highly variable $\mathrm{Mg} / \mathrm{Si}$ ratios and $\mathrm{Ca}$ contents (Falk \& Kelemen, 2015; Nasir et al., 2007; Stanger, 1985), the conversion of peridotite to magnesiterich listvenite at the site of Hole BT1B was nearly isochemical on the whole-core scale except for the addition of $\mathrm{CO}_{2}$. Average bulk rock $\mathrm{Mg} / \mathrm{Si}, \mathrm{Fe} / \mathrm{Si}, \mathrm{Al} / \mathrm{Si}, \mathrm{Fe} / \mathrm{Mg}$, and $\mathrm{Cr} / \mathrm{Al}$ ratios in listvenite are similar to the average composition of the Samail peridotite, while $\mathrm{CaO}$ and correlated $\mathrm{Sr}$ are higher, most likely derived from underlying sediment (Falk \& Kelemen, 2015; Godard et al., 2017; Kelemen et al. 2017, 2020). Thus Mg, Si, Al and Cr, plus Fe were largely immobile on a $10 \mathrm{~m}$ scale during introduction of $\mathrm{C}, \mathrm{O}$, lesser $\mathrm{Ca}$, minor $\mathrm{Fe}$, and mobile trace elements during transformation of $\mathrm{Mg}$-silicates to carbonate + quartz. This implies a large solid volume expansion compared to unaltered peridotite.

\section{Methods \& Materials}

\subsection{Visual core logging}

Cores of Hole BT1B were logged onboard R/V Chikyu in September 2017 by the Oman drilling Phase 1 science team following IODP logging standards (Kelemen et al., 2020). During the macroscopic core logging the host rock was characterized as massive, brecciated, foliated, sheared, cataclastic, or fragmented by veins if the host rock structure was completely obscured by a high vein density. For planar structures that crosscut the host rock, orientation and width could be determined; of these, individual veins, sets of veins, cataclasites, (semi)ductile shear zones, and sharp faults were distinguished. Cataclasites were identified based on the observation of clast sliding and rotation, and fragmentation of particles into a fine grained matrix (Passchier \& Trouw, 2005). First results and datasets of the onboard core logging are available in the online Initial Results volume of the Oman Drilling Project (Kelemen et al., 2020). For this study, we revisited cataclastic structures identified in the onboard logs by inspecting split core images in detail in order to improve the consistency of the dataset with regards to these brittle structures.

\subsection{Samples}

Samples were selected during onboard drill core logging following different criteria, covering the broad (micro)structural and textural diversity of the listvenites to identify the structures related to different stages of carbonation reaction process as opposed to overprinting structures after listvenitization. For this study, we inspected thin sections from 99 samples for the presence of cataclasites. Thin sections from 27 samples that contain cataclasites have been selected for detailed study (Supplementary Table S1).

\subsection{Virtual polarizing microscopy (ViP)}

A high-resolution virtual polarizing microscope platform (ViP) recently developed by the Institute of Structural Geology, Tectonics and Geomechanics (GED, RWTH Aachen 
University) and the Fraunhofer Institute for Life Science Informatics (Virgo et al., 2016) was used for microstructural analysis.

The thin sections selected for this study were scanned in plane polarized and reflected light, and with crossed polarizers at 10 different polarization angles, using a 10x objective. The image data were then processed to extract the extinction curve of each "super pixel", producing giga-pixel images of the extinction behaviour at all polarization angles, which allows for multiscale image analysis. Virtual Petrography datasets and interpretations will be shared publicly via the Oman Drilling Project data repository of the ICDP, together with a virtual microscopy software (TileViewer) that is user friendly and allows Google Earth - like zooming and browsing through the thin section as well as rotation of the polarisers and switching between illumination conditions.

\subsection{Electron microscopy (SEM-EDS)}

257

258

259

260

261

262

263

A Zeiss Gemini SUPRA 55 field-emission electron microscope at the Institute of Structural Geology, Tectonics and Geomechanics (RWTH Aachen University), was used for phase identification and automated energy-dispersive X-ray spectroscopy (EDS) mapping of thin sections. Samples were coated by a $6-8 \mathrm{~nm}$ thick layer of tungsten for conductivity. Operating conditions were $3 \mathrm{kV}$ and $\sim 5 \mathrm{~mm}$ working distance for high magnification imaging, and $15 \mathrm{kV}$ and $8.5 \mathrm{~mm}$ working distance for EDS analysis, at high vacuum, respectively. A dwell time of $200 \mu \mathrm{s} /$ point was chosen for EDS mapping of whole thin sections.

\subsection{Image analysis and grain size distributions}

The EDS data and back-scattered images were processed by applying noise reduction filters and defining thresholds in ImageJ to produce phase maps for the major minerals. Distinction between quartz and amorphous silica, or between magnetite, hematite and Fe-hydroxides, was not possible for large area EDS mapping. We used the particle analysis tool of ImageJ to determine the grain size distribution in selected representative areas of cataclasite, following an approach similar to that of Keulen et al. (2007). Due to the phase variability and the matrix cementation by silica and $\mathrm{Fe}$-(hydr)oxides in many cataclasites, particles were segmented based on magnesite phase maps from EDS data, and on plain polarized ViP microscopy scans. SEM-EDS data allows for higher resolution, whereas the giga-pixel ViP microscopy images provide the particle size distribution of both mineral and lithic clasts on the whole thin-section scale while filtering out the parts of the cataclasite affected by Fe-(hydr)oxide staining and cementation. Late carbonate veins crosscutting the cataclasites have been filtered out based on the particle aspect ratio. To measure the grain size distributions of clasts, the relative frequency of grain areas normalized to the image area and the bin width have been calculated as the number of grains $\mathrm{N}_{\mathrm{i}}$ in each bin i, using 5 logarithmic spaced bins per order of magnitude. Plotting the relative frequency against the grain area in log-log plots yields the local linear slope D of a possible power law distribution (Keulen et al., 2008; Laurich et al., 2018). 


\section{Results}

\subsection{Field relations}

286

Listvenites in the Wadi Mansah and Fanjah regions of the Samail massif form meter to decameter thick bands within serpentinite and along contacts between serpentinite and the metamorphic sole (e.g., Fig. 1c). Commonly two or three such listvenite bands are intercalated in serpentinite and can be followed for several kilometres along strike. Contacts between listvenite and variably serpentinized peridotite are either gradational - composed of a $0.5-3 \mathrm{~m}$ wide transitional zone of carbonate-bearing serpentinite - or consist of strongly deformed, up to $3 \mathrm{~m}$ wide serpentinite fault gouge. Partially hydrated, layered peridotite (i.e. dunite-harzburgite with low degree of serpentinization) was not found in direct contact with listvenite; instead they are separated by a 3-20 m wide layer of (carbonate-bearing) serpentinite, locally with intergrown serpentine and quartz, and/or mineral assemblages including talc (Falk \& Kelemen 2015; Manning et al., 2017). Contacts between listvenite and greenschist to amphibolite facies rocks of the metamorphic sole, Hawasina metasediments, layered gabbro, and Tertiary sediments are commonly characterized by faults with abundant cataclasites, and locally $0.3 \mathrm{~m}$ to $>5 \mathrm{~m}$ of serpentinite fault gouge. Broad folding of the basal fault of the ophiolite north of Wadi Mansah may have locally inverted the original shear sense of these faults. At the southern fold limb, drag folds and striae on slip surfaces at the contacts to the metamorphic sole indicate an apparent top-down sense of shear (Fig. 1c).

Faults and cataclasites ( $<5 \mathrm{~mm}$ to $>2 \mathrm{~m}$ wide) are common in the listvenites in the Samail massif (e.g. Fig. 1d \& e). Striae on fault planes in listvenite suggest an apparent normal, oblique normal or strike-slip sense of shear. Locally, nearly vertical strike-slip faults cut the faults that form the contact between listvenite and the metamorphic sole, with offsets of several meters, indicating that faulting along the contact occurred during an earlier phase of deformation. In general, tilting and rotation of large fault blocks, folding, and the lack of clearly defined marker horizons make it difficult to reconstruct the true sense of shear for the faults in listvenites and serpentinites. Cataclasites in listvenites are cohesive and their sense of shear is often not possible to determine in outcrops. Lithic listvenite clasts in cataclasite are slightly rounded to angular and up to $5-10 \mathrm{~cm}$ in diameter. The cataclasites are cemented by a matrix that is often stained red (silica-rich cataclasites with Fe-oxides) or yellow (dolomiterich cataclasites) in outcrops. In the field, cataclasites are also widespread along fault zones within schist of the metamorphic sole, where they crosscut the metamorphic foliation (Fig. $1 \mathrm{~g}$ ), and in late Paleocene conglomerates that unconformably overlie the ophiolite NE of the village of Fanjah. In serpentinite, it is difficult to detect clear and cohesive cataclasites due to weathering, but occasionally, black (ultra)cataclasites are discernible (Fig. 1f).

\subsection{Hole BT1B}

Core logging has revealed a diverse petrology and structure, from serpentinite with peridotite relics, massive listvenite, foliated listvenite, several generations of veins, ductile shear zones, cataclasite, breccia and planar faults (Kelemen et al., 2020).

The density of veins in the core is very high, > 100 per m (Manning et al., 2017). Both the serpentinite and listvenite in the core contain and are overprinted by several generations of veins, cataclasites, sharp planar faults and late, partially open veins. The earliest type of magnesite vein, which occurs in both serpentinite and listvenite, is antitaxial. In the upper part 
of Hole BT1B, this earliest vein type includes a median line rich in iron oxides (haematite, goethite). Quartz + chalcedony +/- carbonate veins are syntaxial and younger, based on crosscutting relationships. These structures are overprinted by cataclasites and breccia, often enriched in iron oxides, and sharp, planar faults with silica or carbonate veins on the slip surface. Syntaxial, partially open veins of magnesite or dolomite are the latest structures. Cross-cutting relations may not be the same everywhere in the core, and structures belonging to one generation may or may not be synchronous.

334 Listvenite not affected by overprinting (i.e. "primary listvenite") can be massive, containing spheroidal magnesite grains and pseudomorphs of the typical mesh and bastite textures of

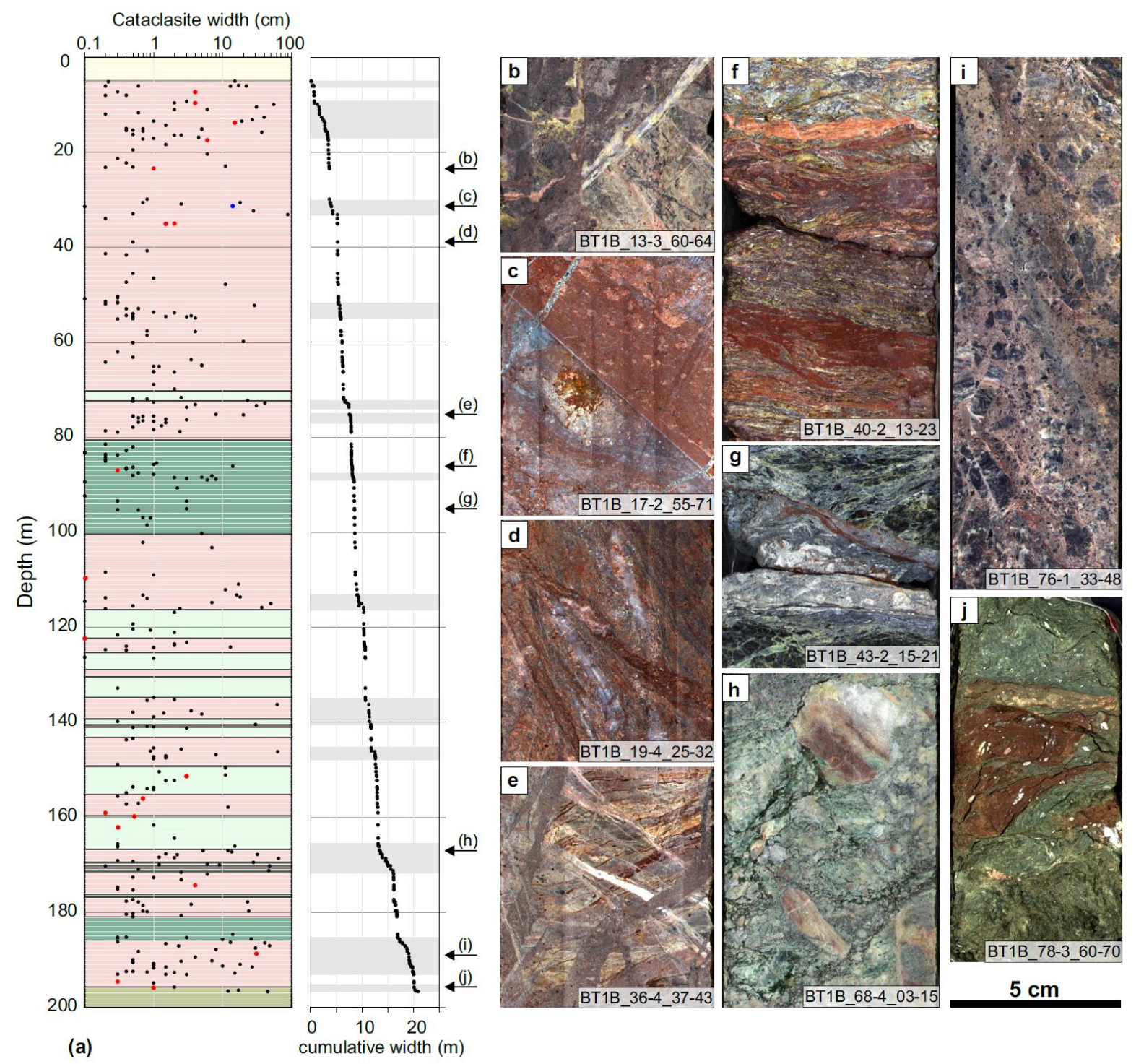

Fig. 2 Macroscopically identified cataclasites in the upper $200 \mathrm{~m}$ of Hole BT1B. (a) Plots of occurrences and width of all logged cataclasites (red data points show cataclasites confirmed in thin section; color coding of lithologies as in Fig. 1b) and their cumulative width with depth in Hole BT1B (grey shadings highlight intense brittle deformed intervals); (b - e) core scan images of examples of cataclasites in the upper listvenites; ( $\mathrm{f} \& \mathrm{~g}$ ) cataclasite in the upper serpentinite layer; (h \& i) cataclasite in the lower listvenites; and (j) fault gouge at the contact to the metamorphic sole. 
serpentinite (Beinlich et al., 2020; Jöns and Bach, 2013; Lafay et al., 2020). In other parts of the core, primary listvenite has a well-developed foliation defined by lithological banding and at the microscale ellipsoidal carbonate particles with an iron oxide core. Shear bands with a locally well-developed foliation are common in the serpentinite, and also in the transition between serpentinite and listvenite, where there are no discernible faults or cataclasites.

\subsubsection{Macroscopically identified cataclasites in Hole BT1B}

Figure 2 shows a plot of the occurrences of macroscopically identified cataclasites with depth and split-core images of cataclasites in listvenite and serpentinite in Hole BT1B. Cataclasites occur throughout most of the core, with particularly thick or abundant cataclasite intervals between 5-18 m, 51 - 55 m, 146-151 m, 166 - $172 \mathrm{~m}$, and 185 - $192 \mathrm{~m}$ depth (Fig. 2a). A $55 \mathrm{~cm}$ wide fault gouge (Fig. $2 \mathrm{j}$ ) forms the contact between listvenite and the metamorphic sole at $197 \mathrm{~m}$ depth. This clay-rich, granular gouge is texturally distinct from the cohesive cataclasites within listvenite core.

In total 352 cataclasites were identified macroscopically in the upper $200 \mathrm{~m}$ of Hole BT1B, with a cumulative width of about $21 \mathrm{~m}$ (Fig. 2a). Hence, about $10 \mathrm{vol} \%$ of listvenite and serpentinite in Hole BT1B is composed of cataclasite. This estimate only includes sections where clast rotation and a high degree of fragmentation typical of cataclasis occurred; the additional thickness of damage zones with cracked grains and a high abundance of small-scale faults in the rock adjacent to cataclasites is often substantial.

The width of single cataclasite bands varies significantly throughout the core $(0.1 \mathrm{~cm}-1 \mathrm{~m})$. For wide cataclasites, orientation and true thickness could not be determined from the core sections and the estimated true width is somewhat uncertain. The lack of macroscopically visible cataclasites does not exclude their presence: in several cases, $<1 \mathrm{~mm}$ wide cataclasite bands are visible in thin sections of samples without macroscopically visible cataclasis. Most cataclasites are cohesive and form anastomosing and branched bands (Fig. 2d, e). Wide cataclasites $(>3 \mathrm{~cm})$ occasionally display internal flow banding of small grained matrix-rich domains that envelop coarse, variably cracked clasts (Fig. 2 c, i). Locally several cataclasite generations overprint each other and are crosscut by sharp faults (e.g. Fig. 2c). Fe-hydroxide staining is common in the matrix of many cataclasites, in particular in the upper $60 \mathrm{~m}$ of Hole BT1B. The amount of displacement related to cataclasites is rarely measurable in the core (e.g. Fig. 2d), perhaps because many have displacements larger than the $6.4 \mathrm{~cm}$ (HQ) and 4.8 $\mathrm{cm}$ (NQ) core diameter. However, there are no cataclasites containing listvenite or metamorphic sole lithologies within serpentinite host rocks, none containing serpentinite or sole lithologies within listvenite, and none containing listvenite or serpentinite within the sole, suggesting that displacements along the cataclasites near contacts are less than a few meters.

\subsubsection{Microstructure of cataclasites in listvenites}

Cataclasites are composed of quartz/chalcedony, magnesite, dolomite and oxide mineral clasts (grain sizes ranging from below 0.2 to $500 \mu \mathrm{m}$ ), and different lithic clasts of variable size. Magnesite mineral clasts are very common in cataclasite, whereas larger quartz clasts are rare (probably due to the generally small grain size of quartz/chalcedony in the host listvenite). Lithic clasts can contain fragments of listvenite composed of magnesite spheroids and interstitial quartz - a common microstructure in listvenite of Hole BT1B (Fig. 3). Larger clasts occasionally contain fragments of veins that crosscut the listvenite. Other lithic clasts 
are fragments of magnesite veins, chalcedony-magnesite veins, quartz veins, breccia and cataclasite. Clasts are commonly rotated and rounded - in particular where cataclasites have been reactivated several times (Fig. 3c). Magnesite mineral clasts locally show a chemical zonation of $\mathrm{Fe}$ contents - similar to magnesite in host listvenite (e.g. Beinlich et al., 2020;

383

384

385

386

387

388

389

390

391

392 Lafay et al., 2020). The Fe zonation is truncated sharply at the rims of magnesite clasts (Fig. 4b). Relict Cr-spinel is strongly fragmented (grain sizes $<5$ to $>500 \mu \mathrm{m}$ ) and can serve as a strain indicator where stretched into trails of dismembered grains (Fig. 4a). Red staining of some cataclasites is due to fine grained hematite and goethite $(<20 \mu \mathrm{m})$ that decorate clast rims and occur interstitially in the fine-grained matrix. In contrast to angular and fragmented Cr-spinel, hematite in the cataclasite matrix displays subhedral to euhedral grains that are partly rounded or form small acicular and atoll shaped aggregates (Fig. 4b). The smallest grain size fraction (matrix) is commonly dominated by quartz/chalcedony and a smaller proportion of magnesite fragments. Dark-coloured, discontinuous ultracataclasite seams and bands $(<100 \mu \mathrm{m}$ wide) occur within cataclasites and at their boundary with the listvenite host
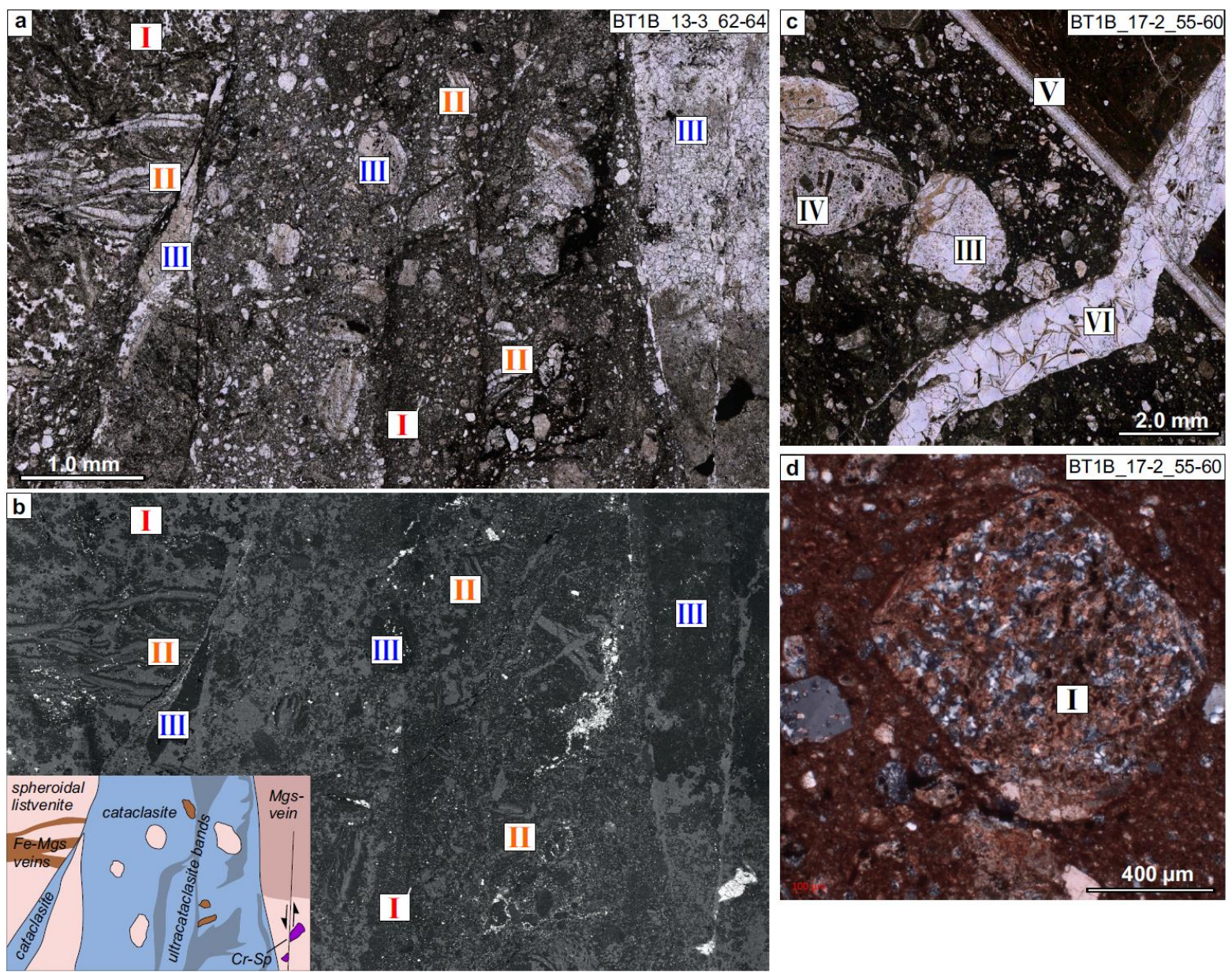

Fig. 3 Listvenite cataclasite microstructures. (a \& b) ViP plane polarized (ppol) micrograph and BSE image of localized cataclasite, showing clasts of listvenite with magnesite spheroids (I) and vein fragments (II, III), and corresponding microstructures in the host listvenite. A simplified interpretative sketch is given in the inset in b). (c) Reworked cataclasite with breccia clast (IV). A sharp fault with dolomite-calcite and quartz veins (V), and a dolomite vein (VI) crosscut cataclasite (ViP ppol). (d) Clast with magnesite spheroids and Fehydroxide staining in cataclasite matrix (crossed polarizers). 

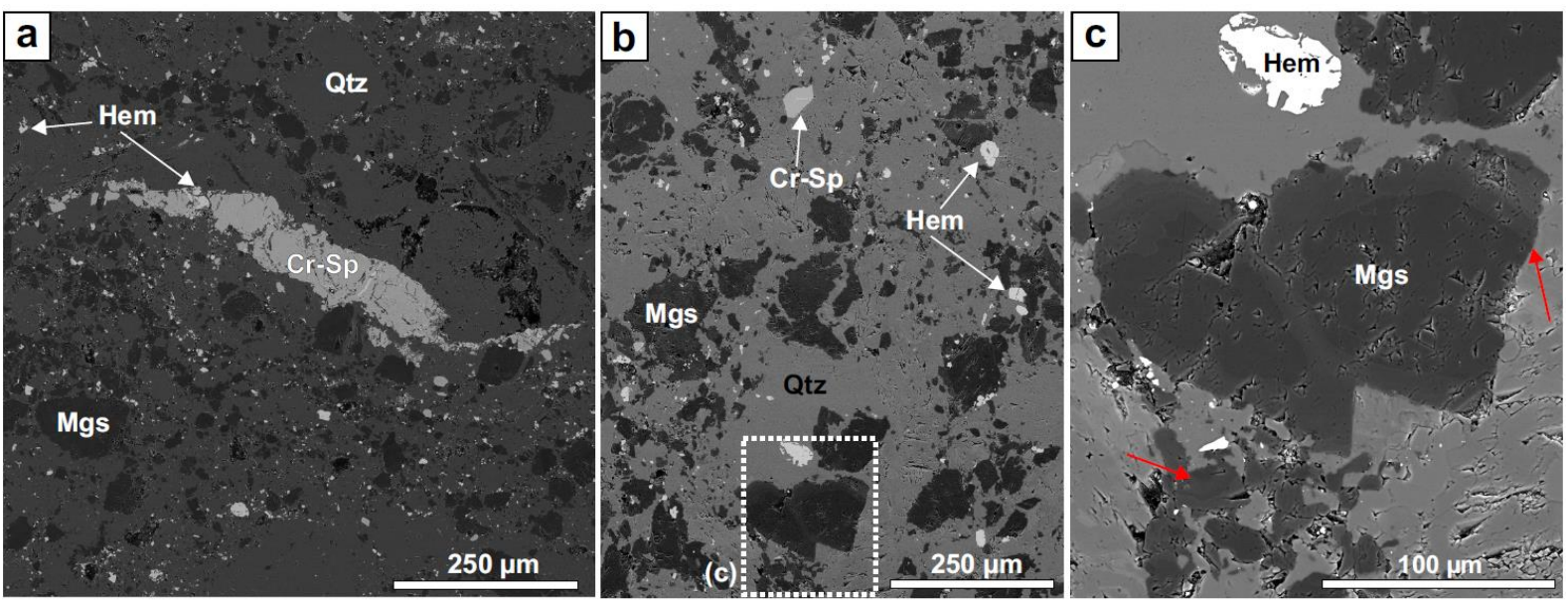

Fig. 4 BSE images of Fe-(hydr)oxide stained cataclasites. (a) Stretched and fragmented Crspinel suggesting sinistral shear (sample BT1B_17-2_55-60). (b) Angular fragments of Crspinel vs. rounded to subhedral hematite grains and aggregates in cataclasite matrix. (c) Detail from b), showing truncation and fragmentation of chemically zoned magnesite clast (red arrows). (b \& c: sample BT1B_9-3_28-31; in these images contrast and brightness have been adjusted to enhance visibility of the zonation in magnesite).

rock, commonly oriented sub-parallel to the main cataclasite. Sharp faults often crosscut cataclasites or are localized along their contact with the host listvenite.

Clast sizes from $50-50000 \mu \mathrm{m}^{2}$ in a prominent cataclasite at $31.4 \mathrm{~m}$ depth (sample BT1B_17-2_55-60) follow a power law distribution with D values of $\sim 1.9-2.0$ (Fig. 5). Such $\mathrm{D}$ values are typical for cataclasites and fault gouges that are characterized by extensive clast rotation and displacement (e.g. Billi, 2007; Keulen et al., 2008; Laurich et al., 2018). Cataclasites that overprint pre-existing cataclasite contain fewer large clasts and a higher matrix fraction.

\subsubsection{Cross-cutting relationships}

With the exception of the youngest generation of carbonate veins (usually dolomite or dolomite-calcite), most other microstructures in host listvenite are truncated by cataclasites, and fragmented clasts of these earlier structures are present within the cataclasites. The microstructures overprinted by cataclasite include host listvenite with a spheroidal to euhedral magnesite habit (Fig. 3a-I, Fig. 3d), antitaxial magnesite veins displaying Fe zonation (Fig. 3a-II), microcrystalline quartz veins, and magnesite-chalcedony veins (Fig. 3a-III). Besides truncation and fragmentation of host listvenite structures, different cataclasite generations overprint each other, with thin localized cataclasite bands crosscutting or reactivating older ones (cf. breccia clast in cataclasite, Fig. 3c-IV).

Figure 6 is a good example of the youngest microstructures and their cross-cutting relations in Hole BT1B, showing a sharp fault juxtaposing two distinct cataclasite generations $(\alpha \& \beta$ in Fig. 6). The highly localized slip plane is marked by an up to $1.5 \mathrm{~mm}$ wide, red-stained ultracataclasite band ( $\gamma$, Fig. 6), and by a $250 \mu \mathrm{m}$ wide vein of microcrystalline quartz precipitated after faulting. Cataclasites, fault and the quartz vein were then crosscut by syntaxial, coarse-grained dolomite veins. The youngest microstructure is a dolomite-calcite 


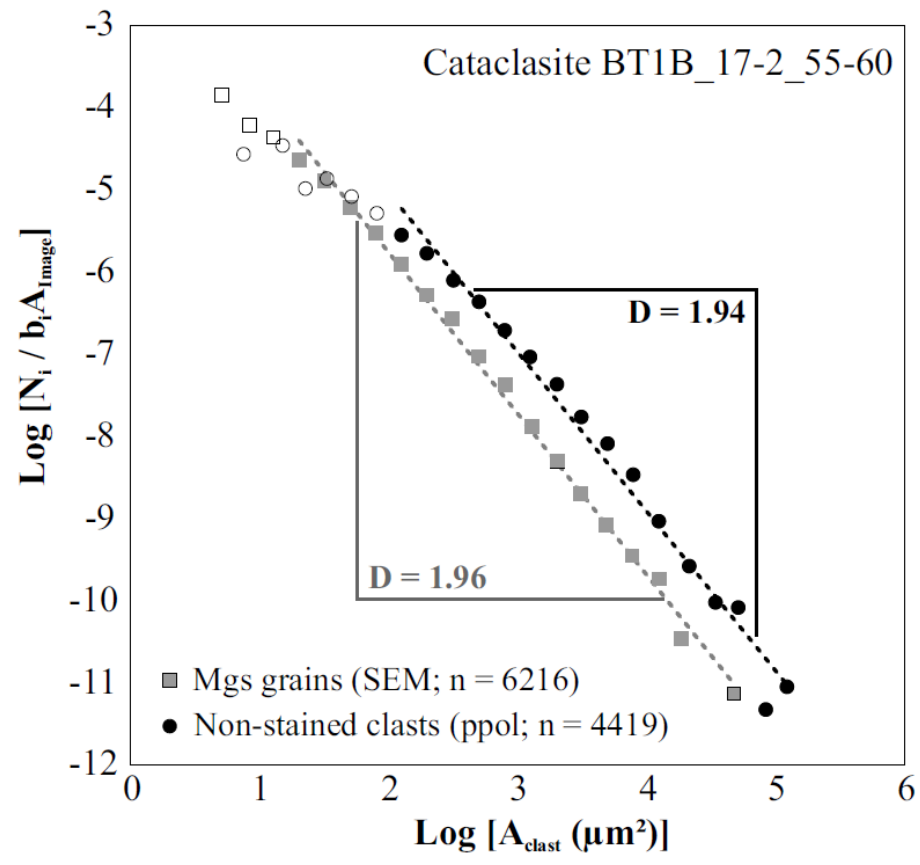

Fig. 5 Grain size distribution of listvenite cataclasite, showing a log-log plot of clast frequency $\mathrm{N}_{\mathrm{i}}$ versus area $\mathrm{A}$. Frequency is normalized to the bin width and the image area, for 5 logarithmic bins per order of magnitude. Similar D values (slope of the power-law fit to curves) are obtained from image segmentation of magnesite grains (by SEM-EDS mapping), and from clasts that are not stained by Fe-hydroxides (by plain polarized mosaic microscopy image, ViP) when the smallest, least reliable grain fractions are excluded.

vein that partly follows the quartz vein along the fault plane and deflects into the dolomite vein. This is consistent with the observation that the youngest veins in field outcrops and throughout Hole BT1B often are composed of dolomite ( \pm calcite), forming syntaxial veins, partially open veins and the matrix of hydraulic/hydrothermal breccias.

\subsubsection{Chemical characteristics of cataclasite}

SEM-EDS chemical mapping shows that in many cases, fluid flow during or after cataclasis modified the $\mathrm{Mg} / \mathrm{Si}$ ratio of listvenite affected by brittle deformation. Different cataclasite generations that overprint each other are affected to variable extent by this chemical modification. Reconstructed EDS spectra of two $400 \mathrm{~mm}^{2}$ areas of different cataclasite generations juxtaposed by a fault in a large thin section of sample BT1B_17-2_55-60 reveal that grey-red cataclasite with a more abundant coarse clast fraction has a molar $\mathrm{Mg} / \mathrm{Si}$ ratio of $\sim 0.49$ ( $\alpha$ in Fig. 6). This is significantly lower than the average molar $\mathrm{Mg} / \mathrm{Si}$ of harzburgite $(1.52-1.54)$ and dunite $(1.75-1.80)$ of the Samail ophiolite (Godard et al., 2000; Hanghøj et al., 2010; Monnier et al., 2006), and lower than average listvenite in Hole BT1B ( 1.48; Kelemen et al., 2020). Red-stained, finer grained cataclasite in the area above the fault shows more rounded mineral and lithic clasts, and has even lower $\mathrm{Mg} / \mathrm{Si}$ of $\sim 0.18$ ( $\beta$ in Fig. 6). And the $\mathrm{Mg} / \mathrm{Si}$ ratio is as low as 0.01 in the $1.5 \mathrm{~mm}$ wide, silica-dominated ultracataclasite band adjacent to the fault slip plane, which is mostly composed of a fine-grained matrix with only few clasts $(\gamma$, Fig. 6). A similar, variable enrichment of Si relative to $\mathrm{Mg}$ in comparison to the host listvenite is evident in most of the cataclasites we studied in detail (e.g. Fig. 7a \& b). In 


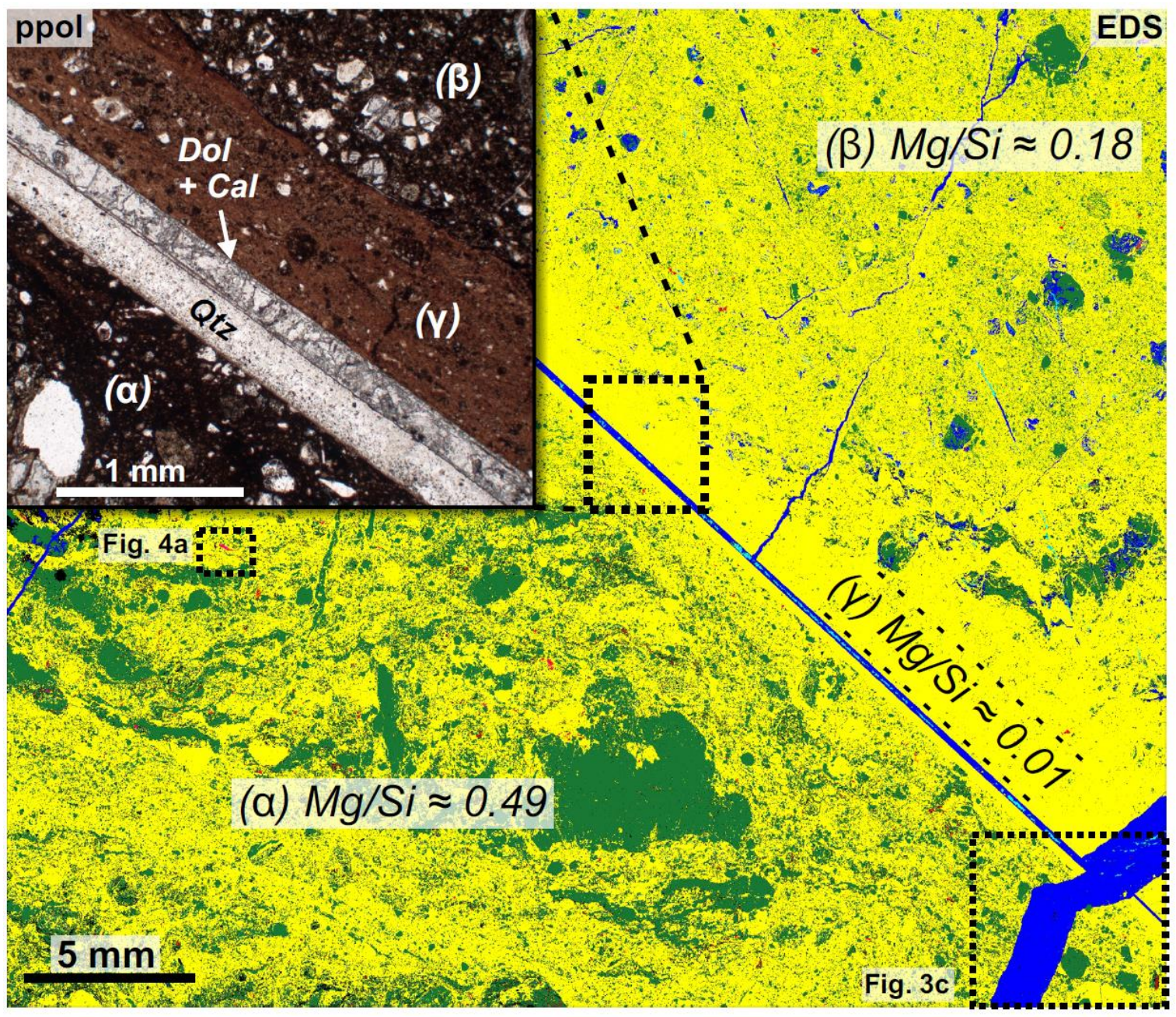

Fig. 6 Variation of silica and carbonate contents in reworked cataclastic listvenite. Large area EDS phase map of two cataclasite generations $(\alpha, \beta)$ separated by an ultracataclasite $(\gamma)$ and a fault (sample BT1B_17-2_55-60), showing quartz (yellow), magnesite (green), dolomite (dark blue), calcite (cyan), Fe-oxide (red) and Cr-spinel (magenta). The inset in the upper left shows a detail ppol image of the ultracataclasite $(\gamma)$, and quartz and calcite-dolomite veins along the sharp fault. Average $\mathrm{Mg} / \mathrm{Si}$ values were calculated using reconstructed EDS spectra integrated over representative areas of the different reworked cataclasite generations.

addition, locally thin $(<2 \mathrm{~mm})$ ultracataclastic bands composed of quartz clasts cemented by a Cr-Al-Fe-hydroxide nanoscale phase cut previous cataclasite generations (Fig. 7). The nanophase is slightly enriched in $\mathrm{Zn}$, and occurs in cataclasite that may contain kaolinite, but where chromian mica is absent. Small clasts of $\mathrm{Cr}$-spinel are similarly abundant in these bands as in other cataclasites. In sample BT1B_17-2_55-60 thin veins of a similar Cr-Al-Fehydroxide locally crosscut cataclasite, but are truncated by the sharp fault.

443 Dolomite-cemented breccias occur throughout listvenite in core from Hole BT1B. In 444 macroscopic observation, these can be similar to listvenite cataclasites, with partially rotated, 445 angular fragments of highly variable grain size. However, EDS chemical mapping revealed 446 that their matrix is consistently composed of dolomite - in contrast to fine grained quartz and magnesite clasts in cataclasite - and the breccias display a continuous variation in texture, grading into the late dolomite vein network (Fig. 8). We interpret these breccias to have 

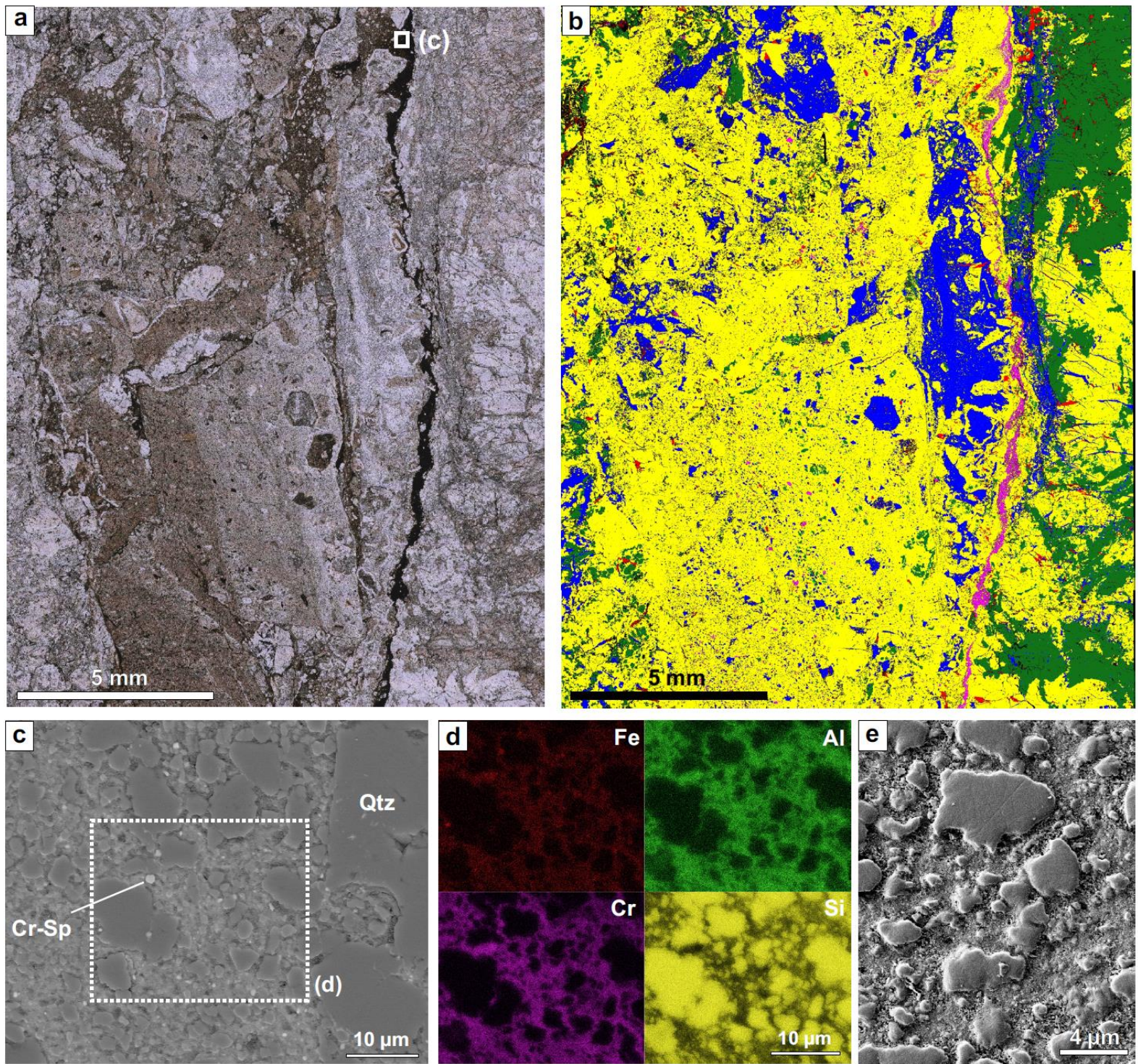

Fig. 7 Vertically oriented and multiply reactivated listvenite cataclasite with late, dark ultracataclastic band (sample BT1B_65-2_22-26). (a) Plain polarized overview (ViP). b) Phase map from SEM-EDS mapping (yellow = quartz; green = magnesite; blue = dolomite; red $=$ kaolinite/clay; magenta $=$ Cr-rich phases). The cataclasite is reworked and has significantly less magnesite than the host listvenite on the right and left sides of the image. (c) BSE image of dark ultracataclastic band in a); darker clasts are quartz/silica. (d) EDS chemical maps of area in c) showing cementation of quartz clasts by an interstitial $\mathrm{Cr}-\mathrm{Al}-\mathrm{Fe}$ nano-phase. (e) SE image of quartz $\mu$-clasts cemented by the interstitial Cr-Al-Fe-phase. 


\section{Discussion}

\subsection{Relative timing of listvenite formation and cataclasis}

454

Cataclastic deformation could in principle provide a positive feedback for the replacement of peridotite by listvenite due to mechanically enhanced reaction rates, if cataclasis was coeval with carbonation (Lisabeth et al., 2017). However, in the case of the thin sections we analysed, composed of macroscopically well-defined cataclasites of Hole BT1B, the microstructures consistently show that cataclasis occurred in previously formed listvenites. This is shown by truncated clasts of listvenite with spheroidal magnesite, fragments of magnesite and chalcedony-magnesite veins that elsewhere crosscut listvenite, and reworked breccia fragments, all within cataclasites. The observation of truncated growth zonation at the rims of fragmented magnesite clasts (Fig. 4b) provides further evidence that cataclasites formed after listvenite formation.

The widespread occurrence of cataclasites throughout listvenites of the core from Hole BT1B, and the common reactivation and reworking of older cataclasites by younger cataclasites and faults, indicates a multiphase, distributed, brittle, post-listvenite deformation in Hole BT1B, perhaps in a relay zone between larger faults. Our study shows that the most evident records of brittle shear - cataclasites composed of listvenite fragments - formed after the formation of listvenite. Nevertheless, it is possible that earlier examples of cataclasites occur elsewhere in the Oman listvenite, and that cataclasis before or during listvenite formation may have been obscured in the core due to subsequent overprint by veins or dissolution-reprecipitation reactions.

\subsection{Fluid flow and chemical modification in listvenite cataclasites}

SEM-EDS chemical mapping revealed that in most of the studied samples, cataclasites have a significantly lower $\mathrm{Mg} / \mathrm{Si}$ ratio than the host listvenite, indicating the local dissolution of magnesite and/or addition of $\mathrm{SiO}_{2}$. The results show that repeated reactivation and reworking to subsequently finer grained cataclasite was correlated with increased $\mathrm{Mg}$ loss and/or silica enrichment (Fig. 6), suggesting that this bulk chemical modification was related to the fluids present during and shortly after cataclastic deformation. Thermodynamic reaction path modelling at relatively low temperatures $\left(100^{\circ} \mathrm{C}\right)$ suggests that extremely high fluid/rock ratios could lead to complete carbonate dissolution together with silica enrichment (i.e. birbirite formation) produced by the same fluids that form listvenite at lower fluid/rock ratios (Klein \& Garrido, 2011). Because the solubility of silica increases with temperature while that of magnesite decreases, and the thermodynamic models of Klein \& Garrido (2011) predict birbirite formation and low $\mathrm{pH}$ at $100^{\circ} \mathrm{C}$, but not 200,300 or $400^{\circ} \mathrm{C}$, the observed silica addition and/or $\mathrm{Mg}$ loss in cataclastic listvenite are consistent with the geothermometry constraints to $80-130{ }^{\circ} \mathrm{C}$ for listvenite formation (Falk \& Kelemen, 2015).

Thin, ultracataclastic bands cemented by a Cr-Al-Fe-hydroxide nano-phase that represent the last cataclasite generation (Fig. 7) likely formed from low pH fluids. At $90{ }^{\circ} \mathrm{C}$, experiments and thermodynamic calculations indicate that $\mathrm{Cr}$ is $\sim 4$ orders of magnitude more soluble in aqueous fluids at $\mathrm{pH} 4$ than at $\mathrm{pH} \mathrm{6,} \mathrm{whereas} \mathrm{it} \mathrm{is} \mathrm{largely} \mathrm{insoluble} \mathrm{at} \mathrm{neutral} \mathrm{and} \mathrm{moderately}$ alkaline pH (Rai et al., 1987). Therefore, Cr mobilization in aqueous fluids is incompatible with the slightly alkaline conditions buffered by carbonate dissolution and likely minor in high pH fluids produced by serpentinization (Chavagnac et al., 2013; Giampouras et al., 2020; 
Paukert et al., 2012). The absence of chromian mica and the presence of kaolinite in the vicinity of ultracataclasite bands cemented by the $\mathrm{Cr}$-Al-Fe-hydroxide nano-phase (Fig. 7b) is consistent with the higher dissolution rates of mica at lower pH (Pachana et al., 2012), suggesting $\mathrm{Cr}$ remobilization due to mica dissolution in addition to chromite alteration. A slightly acidic $\mathrm{pH}$ of fluids related to cataclasite cementation is further in agreement with the inferred local carbonate dissolution (Fig. 6), and indicates that fluids were out of equilibrium with listvenite during this stage of reaction and deformation. We interpret the observation that $\mathrm{Cr}$-Al-Fe-hydroxide veins are rare, while $\mathrm{Cr}$-spinel fragments are common in cataclasites, to be due to the $\mathrm{pH}$ buffer capacity of magnesite dissolution, which prevented larger scale remobilization of $\mathrm{Cr}$.

The observation that dolomite and dolomite-calcite veins often crosscut cataclasites (Fig. 8), breccias, and faults, suggests that part of the Ca gain with respect to mantle peridotite, as observed in the Oman listvenites (Falk \& Kelemen, 2015; Godard et al., 2017; Kelemen et al., 2017; Kelemen et al., 2020), may be related to late fluids after the main listvenite formation occurred. Some of the young dolomite and dolomite-calcite may have precipitated from fluid derived from unconformably overlying Tertiary limestone (de Obeso and Kelemen, 2018) or may be of meteoric origin, similar to the widespread surface-near occurrence of carbonate veins and travertine deposits in the Oman peridotites (Giampouras et al., 2020; Noël et al., 2018; Streit et al., 2012). Scharf et al. (2020) report a U/Pb age of 55 \pm 4 Ma for calcite veins cutting listvenite near the village of Fanjah, consistent with the hypothesis that fluid flow during Eocene deformation may have redistributed $\mathrm{Ca}$ in the listvenites, and/or introduced additional $\mathrm{Ca}$ from sediments above or below the ophiolite.

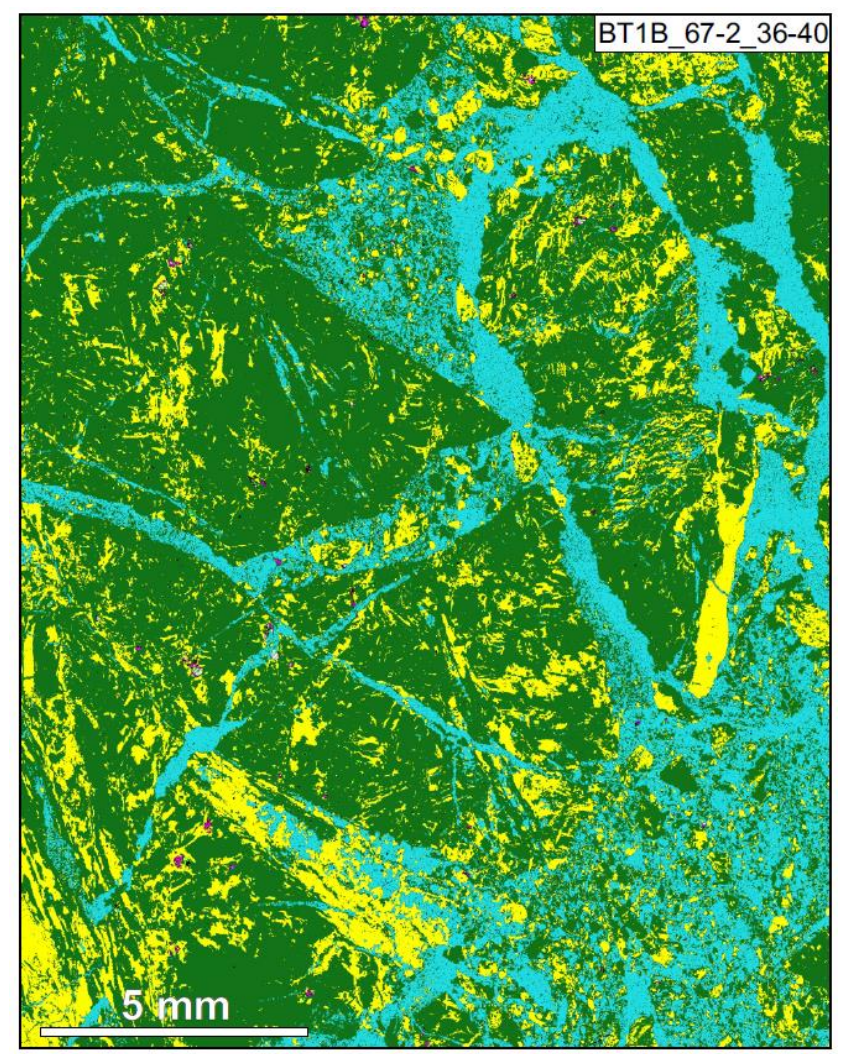

Fig. 8 SEM-EDS phase-map of dolomite-cemented breccia in listvenite, with quartz (yellow), magnesite (green), dolomite (light-blue) and Cr-spinel (magenta). 


\subsection{Relationship with post-obduction tectonics}

In the absence of absolute dating of the cataclastic listvenite, three main, protracted tectonic phases could be related to cataclastic deformation of the basal peridotites and listvenites: (i) brittle thrusting during ophiolite obduction (Fig. 9a), (ii) post-obduction extensional shear zones or reactivation ("retrocharriage") of previous reverse faults (e.g., Gray \& Gregory, 2003) (Fig. 9b), and/or (iii) late oblique normal or strike slip faulting related to uplift of the Jebel Akhdar and Saih Hatat anticlinoria (Fig. 9c, d).

Ophiolite obduction onto the continental platform was followed by ductile top to the NEshear along listric shear zones, normal to oblique-slip faults of late Cretaceous to early Paleogene age, and subsequent strike-slip faults during the Eocene in limestone (Fig. $9 \mathrm{~b}-\mathrm{d}$; cf. Sec. 2.1), accompanying the exhumation of the autochthonous continental margin in the Jebel Akhdar and Saih Hatat anticlinoria (Gomez-Rivas et al., 2014; Grobe et al., 2018; Grobe et al., 2019; Hansman et al., 2018). Because the strength of magnesite is significantly higher than that of calcite limestones (Holyoke et al., 2014), extensional deformation recorded by ductile top to the NE- shear zones in the carbonate platform (Fig. 9b) may have been related to cataclasis in listvenite, possibly reactivating earlier structures.

Cataclasites could have continued to form during subsequent faulting of the carbonate platform in the early Paleogene to Eocene (Fig. 9c), which may be recorded by some of the faults in listvenite and at many of the contacts between listvenite, serpentinite and the metamorphic sole (Fig. 1a \& c). The abundance of calcite veins in the Cretaceous section below the ophiolite (Grobe et al., 2018) points to a significant amount of fluid flow during this phase. Fluid inclusion thermometry in quartz and calcite veins in the limestones indicate cooling from about $220-130{ }^{\circ} \mathrm{C}$ during the transition from normal to strike-slip faulting during exhumation of the Jebel Akhdar (Grobe et al., 2019). In the Saih Hatat, uplift and cooling started somewhat earlier, reaching $120-90{ }^{\circ} \mathrm{C}$ in the Eocene (Hansman et al., 2017). Reactivation of listvenite cataclasites by sharp faults and the formation of dolomite-cemented breccias in the Wadi Mansah area may be partly related to the uplift of the erosional surface atop the Jebel Akhdar and Saih Hatat anticlinoria to their current high topography (Fig. 9d) and the development of the Samail gap fault zone (Scharf et al., 2019).

\subsection{Cataclasis - a positive feedback mechanism for carbonation?}

The close spatial relation of listvenites with the basal thrust and other faults in Oman and other ophiolites (Ash \& Arksey, 1989; Menzel et al., 2018; Qiu and Zhu, 2018) suggests that the interplay between major tectonic deformation and fluid flux may play a key role in large scale formation of listvenites. In these settings, cataclasites and dilatant faults and veins are likely to occur, which may enhance reactivity with $\mathrm{CO}_{2}$-bearing fluids (Lisabeth et al., 2017). On the other hand, our results demonstrate that a tectonic overprint post-dating listvenite formation - and related fluid flow and chemical modification - can be substantial and should be filtered out in order to understand the mechanisms that sustain fluid flow and carbonation reactions. In contrast, earlier veins, such as antitaxial magnesite veins, formed along fractures, and record brittle deformation that may have played an important role in maintaining or enhancing permeability and continued influx of $\mathrm{CO}_{2}$-bearing fluids required for listvenite formation. 

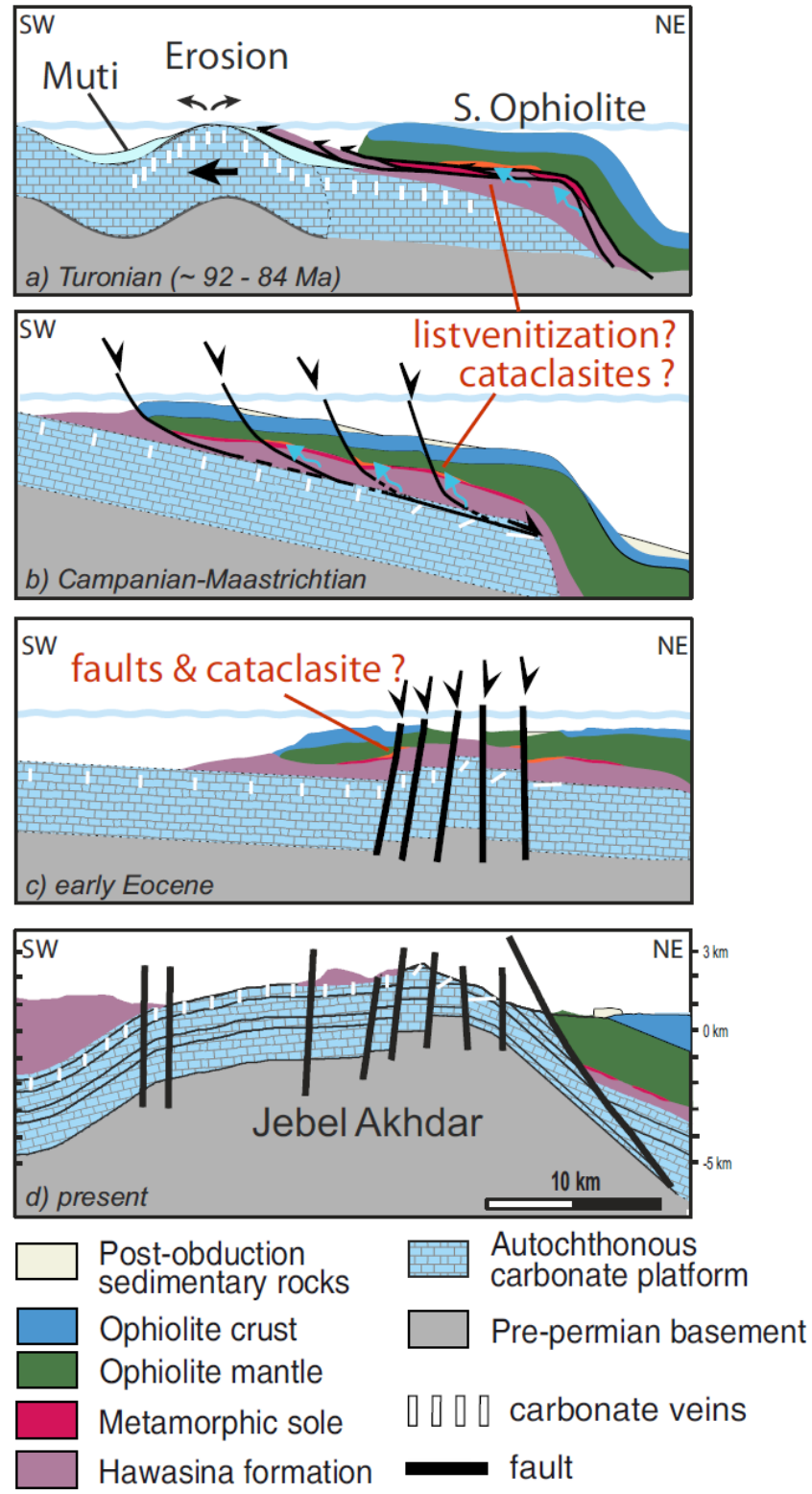

Fig. 9 Sketch of the simplified post-obduction tectonic evolution of the Samail ophiolite and carbonate platform in Oman (after Grobe et al., 2018), with potential stages of brittle deformation in listvenite at the base of the ophiolite (orange).

\section{Conclusions}

1. Visual core logging shows that about $10 \mathrm{vol} \%$ of listvenite and serpentinite throughout Hole BT1B has been converted to cataclasite. Continuous core sections $>1 \mathrm{~m}$ without cataclasites are rare. The width of cataclastic bands in listvenite ranges from $<1 \mathrm{~mm}$ to $>$ $100 \mathrm{~cm}$. Brittle grain size reduction led to a power-law grain size distribution in cataclasites with rounded clasts. We interpret this to be formed by multiple phases of movement in an array of small ( $\mathrm{dm}-\mathrm{m}$ scale) faults. 
2. In all samples with thin sections of macroscopically identified cataclasites, the microstructures show that cataclasis overprints previously formed listvenites, as indicated by truncated clasts of host listvenite with spheroidal magnesite habit, fragments of chalcedony-magnesite veins, and reworked breccia fragments in cataclasite.

3. Sharp faults, dolomite veins and dolomite-calcite veins crosscut listvenite cataclasites and are the youngest brittle deformation structures in the core.

4. SEM-EDS chemical mapping reveals that cataclasites commonly have a lower $\mathrm{Mg} / \mathrm{Si}$ ratio than the host listvenite, indicating the local dissolution of magnesite and/or addition of $\mathrm{SiO}_{2}$ in cataclasites by reactive fluids.

5. Thin ultracataclastic bands with an interstitial Cr-Al-Fe hydroxide nano-phase are the last cataclasite generation. The mobilioty of $\mathrm{Cr}$ and $\mathrm{Al}$ in this process suggests that they formed from acidic aqueous fluids $(\mathrm{pH} \leq 4)$ related to dissolution of magnesite and chromian mica.

6. Repeated brittle overprinting and reactivation of cataclastic listvenite in the field and Hole BT1B core show that there were multiple brittle deformation events post-dating listvenite formation in the basal section of the Samial ophiolite. Some or all of this multistage brittle overprint of listvenite by cataclasites, faults and late veins may be related to the evolution of the sedimentary continental margin units underlying the ophiolite after obduction.

7. Post-obduction brittle deformation with related fluid flow and local chemical overprint is likely common in the basal section of the Samail ophiolite, Oman, and should be excluded when analyzing earlier structures to understand the chemo-mechanical process of listvenite formation. 
MDM and JLU acknowledge funding by the German Research Foundation (DFG grant UR 64/20-1). This research used samples and data provided by the Oman Drilling Project. The Oman Drilling Project (OmanDP) has been possible through co-mingled funds from the International Continental Scientific Drilling Project (ICDP; Kelemen, Matter, Teagle Lead PIs), the Sloan Foundation - Deep Carbon Observatory (Grant 2014-3-01, Kelemen PI), the National Science Foundation (NSF-EAR-1516300, Kelemen lead PI), NASA - Astrobiology Institute NNA15BB02A, Templeton PI), the German Research Foundation (DFG: KO 1723/21-1, Koepke PI), the Japanese Society for the Promotion of Science (JSPS no:16H06347, Michibayashi PI; and KAKENHI 16H02742, Takazawa PI), the European Research Council (Adv: no.669972; Jamveit PI), the Swiss National Science Foundation (SNF:20FI21_163073, Früh-Green PI), JAMSTEC, the TAMU-JR Science Operator, and contributions from the Sultanate of Oman Ministry of Regional Municipalities and Water Resources, the Oman Public Authority of Mining, Sultan Qaboos University, CRNS-Univ. Montpellier II, Columbia University of New York, and the University of Southampton. We further thank the Oman Public Authority of Mining for permissions to conduct field work and sample export.

\section{Supplementary material}

610 Supplementary Table S1: Overview of studied thin sections of samples with cataclastic structures [will be uploaded to a PANGEA repository]

\section{References}

613

614

615

616

617

618

619

620

621

622

623

624

625

626

627

628

Agard, P., Searle, M. P., Alsop, G. I., \& Dubacq, B. (2010). Crustal stacking and expulsion tectonics during continental subduction: P-T deformation constraints from Oman. Tectonics, 29(5). doi:10.1029/2010TC002669

Akbulut, M., Piskin, O., \& Karayigit, A. I. (2006). The genesis of the carbonatized and silicified ultramafics known as listvenites: a case study from the Mihaliccik region (Eskisehir), NW Turkey. Geological Journal, 41(5), 557-580. doi:10.1002/gj.1058

Al-Wardi, M., \& Butler, R. W. H. (2007). Constrictional extensional tectonics in the northern Oman mountains, its role in culmination development and the exhumation of the subducted Arabian continental margin. Geological Society, London, Special Publications, 272(1), 187. doi:10.1144/GSL.SP.2007.272.01.11

Alt, J. C., Schwarzenbach, E. M., Früh-Green, G. L., Shanks Iii, W. C., Bernasconi, S. M., Garrido, C. J., . . Marchesi, C. (2013). The role of serpentinites in cycling of carbon and sulfur: Seafloor serpentinization and subduction metamorphism. Lithos, 178(0), 40-54. doi:10.1016/j.lithos.2012.12.006

Andreani, M., Luquot, L., Gouze, P., Godard, M., Hoisé, E., \& Gibert, B. (2009). Experimental study of carbon sequestration reactions controlled by the percolation of 
$\mathrm{CO}_{2}$-rich brine through peridotites. Environmental Science \& Technology, 43(4), 1226-1231. doi:10.1021/es8018429

Ash, C. H., \& Arksey, R. L. (1989). The Atlin ultramafic allochthon: ophiolitic basement within the Cache Creek terrane; tectonic and metallogenic significance. British Columbia Geological Survey Field Report, 104N/12.

Béchennec, F., Roger, J., Le Métour, J., \& Wyns, R. (Cartographer). (1992). Geological Map Oman $1: 250.000$, Seeb - Sheet NF40-03

Beinlich, A., Austrheim, H., Mavromatis, V., Grguric, B., Putnis, C. V., \& Putnis, A. (2018). Peridotite weathering is the missing ingredient of Earth's continental crust composition. Nature Communications, 9(1), 634. doi:10.1038/s41467-018-03039-9

Beinlich, A., Plümper, O., Hövelmann, J., Austrheim, H., \& Jamtveit, B. (2012). Massive serpentinite carbonation at Linnajavri, N-Norway. Terra Nova, 24(6), 446-455. doi:10.1111/j.1365-3121.2012.01083.x

Beinlich, A., Plümper, O., Boter, E., Müller, I. A., Kourim, F., Ziegler, M., . . . the Oman Drilling Project Science Team. (2020). Ultramafic rock carbonation: Constraints from listvenite core BT1B, Oman Drilling Project. Journal of Geophysical Research: Solid Earth, $n / a(\mathrm{n} / \mathrm{a})$, e2019JB019060. doi:10.1029/2019JB019060

Billi, A. (2007). On the extent of size range and power law scaling for particles of natural carbonate fault cores. Journal of Structural Geology, 29(9), 1512-1521. doi:https://doi.org/10.1016/j.jsg.2007.06.007

Chavagnac, V., Monnin, C., Ceuleneer, G., Boulart, C., \& Hoareau, G. (2013). Characterization of hyperalkaline fluids produced by low-temperature serpentinization of mantle peridotites in the Oman and Ligurian ophiolites. Geochemistry, geophysics, geosystems, 14(7), 2496-2522. doi:10.1002/ggge.20147

Coleman, R. G. (1981). Tectonic setting for ophiolite obduction in Oman. Journal of Geophysical Research: Solid Earth, 86(B4), 2497-2508. doi:10.1029/JB086iB04p02497

Cowan, R. J., Searle, M. P., \& Waters, D. J. (2014). Structure of the metamorphic sole to the Oman Ophiolite, Sumeini Window and Wadi Tayyin: implications for ophiolite obduction processes. Geological Society, London, Special Publications, 392(1), 155. doi: $10.1144 /$ SP392.8

de Obeso, J. C., \& Kelemen, P. B. (2018). Fluid rock interactions on residual mantle peridotites overlain by shallow oceanic limestones: Insights from Wadi Fins, Sultanate of Oman. Chemical Geology, 498, 139-149. doi:https://doi.org/10.1016/j.chemgeo.2018.09.022

Escayola, M., Proenza, J., van Staal, C., Rogers, N., \& Skulski, T. (2009). The Point Rousse listvenites, Baie Verte, Newfoundland: altered ultramafic rocks with potential for gold mineralization. Current Research Geological Survey Report, 09-1, 1-12. 
Evans, O., Spiegelman, M., \& Kelemen, P. B. (2020). Phase-Field Modeling of ReactionDriven Cracking: Determining Conditions for Extensive Olivine Serpentinization. Journal of Geophysical Research: Solid Earth, 125(1), e2019JB018614. doi:10.1029/2019JB018614

Falk, E. S., \& Kelemen, P. B. (2015). Geochemistry and petrology of listvenite in the Samail ophiolite, Sultanate of Oman: Complete carbonation of peridotite during ophiolite emplacement. Geochimica et Cosmochimica Acta, 160, 70-90. doi:10.1016/j.gca.2015.03.014

Farough, A., Moore, D. E., Lockner, D. A., \& Lowell, R. P. (2016). Evolution of fracture permeability of ultramafic rocks undergoing serpentinization at hydrothermal conditions: An experimental study. Geochemistry, geophysics, geosystems, 17(1), 4455. doi:10.1002/2015GC005973

Ghent, E. D., \& Stout, M. Z. (1981). Metamorphism at the base of the Samail Ophiolite, southeastern Oman Mountains. Journal of Geophysical Research: Solid Earth, 86(B4), 2557-2571. doi:10.1029/JB086iB04p02557

Giampouras, M., Garrido, C. J., Bach, W., Los, C., Fussmann, D., Monien, P., \& García-Ruiz, J. M. (2020). On the controls of mineral assemblages and textures in alkaline springs, Samail Ophiolite, Oman. Chemical Geology, 533, 119435. doi:10.1016/j.chemgeo.2019.119435

Glennie, K. W., Boeuf, M. G. A., Clarke, M. W. H., Moody Stuart, M., Pilaar, W. F. H., \& Reinhardt, B. M. (1974). Geology of the Oman mountains. Verhandelingen van het Koninklink Nederlands Geologisch Mijnbouwkundig Genootschap, 31.

Godard, M., Bennett, E., Carter, E., Kourim, F., Lafay, R., Noël, J., ... \& Harris, M. (2017). Geochemical and Mineralogical Profiles Across the Listvenite-Metamorphic Transition in the Basal Megathrust of the Oman Ophiolite: First Results from Drilling at Oman Drilling Project Hole BT1B. In AGU Fall Meeting 2017, abstracts V24E-07.

Godard, M., Jousselin, D., \& Bodinier, J.-L. (2000). Relationships between geochemistry and structure beneath a palaeo-spreading centre: a study of the mantle section in the Oman ophiolite. Earth and Planetary Science Letters, 180(1), 133-148. doi:https://doi.org/10.1016/S0012-821X(00)00149-7

Godard, M., Luquot, L., Andreani, M., \& Gouze, P. (2013). Incipient hydration of mantle lithosphere at ridges: A reactive-percolation experiment. Earth and Planetary Science Letters, 371-372, 92-102. doi:https://doi.org/10.1016/j.epsl.2013.03.052

Gomez-Rivas, E., Bons, P. D., Koehn, D., Urai, J. L., Arndt, M., Virgo, S., . . Blum, P. (2014). The Jabal Akhdar dome in the Oman Mountains: Evolution of a dynamic fracture system. American Journal of Science, 314(7), 1104-1139.

Grobe, A., Urai, J. L., Littke, R., \& Lünsdorf, N. K. (2016). Hydrocarbon generation and migration under a large overthrust: The carbonate platform under the Semail 
Ophiolite, Jebel Akhdar, Oman. International Journal of Coal Geology, 168, 3-19. doi:https://doi.org/10.1016/j.coal.2016.02.007

Grobe, A., Virgo, S., von Hagke, C., Urai, J. L., \& Littke, R. (2018). Multiphase Structural Evolution of a Continental Margin During Obduction Orogeny: Insights From the Jebel Akhdar Dome, Oman Mountains. Tectonics, 37(3), 888-913. doi:10.1002/2016TC004442

Grobe, A., von Hagke, C., Littke, R., Dunkl, I., Wübbeler, F., Muchez, P., \& Urai, J. L. (2019). Tectono-thermal evolution of Oman's Mesozoic passive continental margin under the obducting Semail Ophiolite: a case study of Jebel Akhdar, Oman. Solid Earth, 10(1), 149-175. doi:10.5194/se-10-149-2019

Guilmette, C., Smit, M. A., van Hinsbergen, D. J. J., Gürer, D., Corfu, F., Charette, B., . . Savard, D. (2018). Forced subduction initiation recorded in the sole and crust of the Semail Ophiolite of Oman. Nature Geoscience, 11(9), 688-695. doi:10.1038/s41561018-0209-2

Hacker, B. R., \& Mosenfelder, J. L. (1996). Metamorphism and deformation along the emplacement thrust of the Samail ophiolite, Oman. Earth and Planetary Science Letters, 144(3), 435-451. doi:https://doi.org/10.1016/S0012-821X(96)00186-0

Hacker, B. R., Mosenfelder, J. L., \& Gnos, E. (1996). Rapid emplacement of the Oman ophiolite: Thermal and geochronologic constraints. Tectonics, 15(6), 1230-1247. doi:10.1029/96TC01973

Halls, C., \& Zhao, R. (1995). Listvenite and related rocks: perspectives on terminology and mineralogy with reference to an occurrence at Cregganbaun, Co. Mayo, Republic of Ireland. Mineralium Deposita, 30(3-4), 303-313. doi:10.1007/bf00196366

Hanghøj, K., Kelemen, P. B., Hassler, D., \& Godard, M. (2010). Composition and Genesis of Depleted Mantle Peridotites from the Wadi Tayin Massif, Oman Ophiolite; Major and Trace Element Geochemistry, and Os Isotope and PGE Systematics. Journal of Petrology, 51(1-2), 201-227. doi:10.1093/petrology/egp077

Hansen, L. D., Dipple, G. M., Gordon, T. M., \& Kellett, D. A. (2005). Carbonated serpentinite (listwanite) at Atlin, British Columbia: A geological analogue to carbon dioxide sequestration. Canadian Mineralogist, 43(1), 225-239.

Hansman, R. J., Albert, R., Gerdes, A., \& Ring, U. (2018). Absolute ages of multiple generations of brittle structures by U-Pb dating of calcite. Geology, 46(3), 207-210. doi:10.1130/G39822.1

Hansman, R. J., Ring, U., Thomson, S. N., den Brok, B., \& Stübner, K. (2017). Late Eocene Uplift of the Al Hajar Mountains, Oman, Supported by Stratigraphy and LowTemperature Thermochronology. Tectonics, 36(12), 3081-3109. doi:10.1002/2017TC004672

Holyoke, C. W., Kronenberg, A. K., Newman, J., \& Ulrich, C. (2014). Rheology of magnesite. Journal of Geophysical Research: Solid Earth, 119(8), 6534-6557. doi:10.1002/2013JB010541 
Hopson, C. A., Coleman, R. G., Gregory, R. T., Pallister, J. S., \& Bailey, E. H. (1981). Geologic section through the Samail Ophiolite and associated rocks along a MuscatIbra Transect, southeastern Oman Mountains. Journal of Geophysical Research: Solid Earth, 86(B4), 2527-2544. doi:10.1029/JB086iB04p02527

Hövelmann, J., Austrheim, H., \& Jamtveit, B. (2013). Microstructure and porosity evolution during experimental carbonation of a natural peridotite. Chemical Geology, 334, 254265. doi:10.1016/j.chemgeo.2012.10.025

Huang, J., Hao, J., Huang, F., \& Sverjensky, D. A. (2019). Mobility of chromium in high temperature crustal and upper mantle fluids. Geochemical Perspectives Letters, 12, 1-6. doi:http://dx.doi.org/10.7185/geochemlet.1926

Hyndman, R. D., \& Peacock, S. M. (2003). Serpentinization of the forearc mantle. Earth and Planetary Science Letters, 212(3-4), 417-432. doi:10.1016/s0012-821x(03)00263-2

Jacobs, J., Thomas, R. J., Ksienzyk, A. K., \& Dunkl, I. (2015). Tracking the Oman Ophiolite to the surface - New fission track and (U-Th)/He data from the Aswad and Khor Fakkan Blocks, United Arab Emirates. Tectonophysics, 644-645, 68-80. doi:https://doi.org/10.1016/j.tecto.2014.12.018

Jöns, N., \& Bach, W. (2013). Serpentinization. In J. Harff, M. Meschede, S. Petersen, \& J. Thiede (Eds.), Encyclopedia of Marine Geosciences (pp. 1-12). Dordrecht: Springer Netherlands.

Kelemen, P. B., Aines, R., Bennett, E., Benson, S. M., Carter, E., Coggon, J. A., . . Wilcox, J. (2018). In situ carbon mineralization in ultramafic rocks: Natural processes and possible engineered methods. Energy Procedia, 146, 92-102. doi:https://doi.org/10.1016/j.egypro.2018.07.013

Kelemen, P., Godard, M., Johnson, K. T. M., Okazaki, K., Manning, C. E., Urai, J. L., . . and the Oman Drilling Project Phase I Science Party. (2017). Peridotite carbonation at the leading edge of the mantle wedge: OmDP Site BT1. AGU Fall meeting, abstract V24E-06.

Kelemen, P. B., \& Hirth, G. (2012). Reaction-driven cracking during retrograde metamorphism: Olivine hydration and carbonation. Earth and Planetary Science Letters, 345-348(Supplement C), 81-89. doi:https://doi.org/10.1016/j.eps1.2012.06.018

Kelemen, P. B., \& Manning, C. E. (2015). Reevaluating carbon fluxes in subduction zones, what goes down, mostly comes up. Proceedings of the National Academy of Sciences, 112(30), E3997-4006. doi:10.1073/pnas.1507889112

Kelemen, P. B., \& Matter, J. (2008). In situ carbonation of peridotite for $\mathrm{CO}_{2}$ storage. Proceedings of the National Academy of Sciences, 105(45), 17295-17300.

Kelemen, P. B., Matter, J., Streit, E. E., Rudge, J. F., Curry, W. B., \& Blusztajn, J. (2011). Rates and Mechanisms of Mineral Carbonation in Peridotite: Natural Processes and Recipes for Enhanced, in situ $\mathrm{CO}_{2}$ Capture and Storage. In R. Jeanloz \& K. H. 
Freeman (Eds.), Annual Review of Earth and Planetary Sciences, Vol 39 (Vol. 39, pp. 545-576).

Kelemen, P.B., Matter, J.M., Teagle, D.A.H., Coggon, J.A., and the Oman Drilling Project Science Team. (2020). Proceedings of the Oman Drilling Project: College Station, TX (International Ocean Discovery Program). https://doi.org/10.14379/OmanDP.proc.2020

Keulen, N., Stünitz, H., \& Heilbronner, R. (2008). Healing microstructures of experimental and natural fault gouge. Journal of Geophysical Research: Solid Earth, 113(B6). doi:10.1029/2007JB005039

Klein, F., \& Garrido, C. J. (2011). Thermodynamic constraints on mineral carbonation of serpentinized peridotite. Lithos, 126(3-4), 147-160. doi:10.1016/j.lithos.2011.07.020

Klein, F., Grozeva, N. G., Seewald, J. S., McCollom, T. M., Humphris, S. E., Moskowitz, B., ... Kahl, W.-A. (2015). Experimental constraints on fluid-rock reactions during incipient serpentinization of harzburgite. American Mineralogist, 100(4), 991-1002. doi:10.2138/am-2015-5112

Lacinska, A. M., \& Styles, M. T. (2012). Silicified serpentinite - a residuum of a Tertiary palaeo-weathering surface in the United Arab Emirates. Geological Magazine, 150(3), 385-395. doi:10.1017/S0016756812000325

Lafay, R., Godard, M., Menzel, M., Beinlich, A., Kourim, F., Decrausaz, T., and the Oman Drilling Project Phase 1 Science Party. Listvenization processes in the mantle atop the Samail ophiolite metamorphic sole: Mineralogical and thermodynamic constraints. Proceedings of the International Conference on Ophiolites and Oceanic Lithosphere, 12-14 January, Sultan Qaboos University, Oman, 2020, page 129.

Laurich, B., Urai, J. L., Vollmer, C., \& Nussbaum, C. (2018). Deformation mechanisms and evolution of the microstructure of gouge in the Main Fault in Opalinus Clay in the Mont Terri rock laboratory (CH). Solid Earth, 9(1), 1-24. doi:10.5194/se-9-1-2018

Li, J., \& Hitch, M. (2018). Mechanical activation of magnesium silicates for mineral carbonation, a review. Minerals Engineering, 128, 69-83. doi:https://doi.org/10.1016/j.mineng.2018.08.034

Lisabeth, H. P., Zhu, W., Kelemen, P. B., \& Ilgen, A. (2017). Experimental evidence for chemo-mechanical coupling during carbon mineralization in ultramafic rocks. Earth and Planetary Science Letters, 474(Supplement C), 355-367. doi:https://doi.org/10.1016/j.eps1.2017.06.045

Macdonald, A. H., \& Fyfe, W. S. (1985). Rate of serpentinization in seafloor environments. Tectonophysics, 116(1), 123-135. doi:https://doi.org/10.1016/0040-1951(85)90225-2

Malthe-Sørenssen, A., Jamtveit, B., \& Meakin, P. (2006). Fracture Patterns Generated by Diffusion Controlled Volume Changing Reactions. Physical Review Letters, 96(24), 245501. doi:10.1103/PhysRevLett.96.245501 
Manning, C. E., Kelemen, P. B., Michibayashi, K., Harris, M., Urai, J. L., de Obeso, J. C., . . and the Oman Drilling Project Phase 1 Science Party. (2017). Transformation of Serpentinite to Listvenite as Recorded in the Vein History of Rocks From Oman Drilling Project Hole BT1B. AGU Fall Meeting Abstract, V24E-08.

Malvoisin, B., Auzande, A.L., Kelemen, P.B., and the Oman Drilling Project Science Party. (2020). The mechanism of fluid pathway preservation during solid volume increase in serpentinization. Geology, submitted April 2020

Menzel, M. D., Garrido, C. J., López Sánchez-Vizcaíno, V., Marchesi, C., Hidas, K., Escayola, M. P., \& Delgado Huertas, A. (2018). Carbonation of mantle peridotite by $\mathrm{CO}_{2}$-rich fluids: the formation of listvenites in the Advocate ophiolite complex (Newfoundland, Canada). Lithos, 323, 238-261. doi:10.1016/j.lithos.2018.06.001

Miller, J. M., Gregory, R. T., Gray, D. R., \& Foster, D. A. (1999). Geological and geochronological constraints on the exhumation of a high-pressure metamorphic terrane, Oman. Geological Society, London, Special Publications, 154(1), 241. doi:10.1144/GSL.SP.1999.154.01.11

Monnier, C., Girardeau, J., Le Mée, L., \& Polvé, M. (2006). Along-ridge petrological segmentation of the mantle in the Oman ophiolite. Geochemistry, geophysics, geosystems, 7(11). doi:10.1029/2006GC001320

Nasir, S., Al Sayigh, A. R., Al Harthy, A., Al-Khirbash, S., Al-Jaaidi, O., Musllam, A., . . Al-Bu'saidi, S. (2007). Mineralogical and geochemical characterization of listwaenite from the Semail Ophiolite, Oman. Geochemistry, 67(3), 213-228. doi:10.1016/j.chemer.2005.01.003

Nicolas, A., \& Boudier, F. (1995). Mapping oceanic ridge segments in Oman ophiolite. Journal of Geophysical Research: Solid Earth, 100(B4), 6179-6197. doi:10.1029/94JB01188

Nicolas, A., Boudier, F., \& Ildefonse, B. (1996). Variable crustal thickness in the Oman ophiolite: Implication for oceanic crust. Journal of Geophysical Research: Solid Earth, 101(B8), 17941-17950. doi:10.1029/96JB00195

Noël, J., Godard, M., Oliot, E., Martinez, I., Williams, M., Boudier, F., . . Gouze, P. (2018). Evidence of polygenetic carbon trapping in the Oman Ophiolite: Petro-structural, geochemical, and carbon and oxygen isotope study of the Wadi Dima harzburgitehosted carbonates (Wadi Tayin massif, Sultanate of Oman). Lithos. doi:https://doi.org/10.1016/j.lithos.2018.08.020

Nolan, S. C., Skelton, P. W., Clissold, B. P., \& Smewing, J. D. (1990). Maastrichtian to early Tertiary stratigraphy and palaeogeography of the Central and Northern Oman Mountains. Geological Society, London, Special Publications, 49(1), 495. doi:10.1144/GSL.SP.1992.049.01.31

Oelkers, E. H., Declercq, J., Saldi, G. D., Gislason, S. R., \& Schott, J. (2018). Olivine dissolution rates: A critical review. Chemical Geology, 500, 1-19. doi:https://doi.org/10.1016/j.chemgeo.2018.10.008 
Pachana, K., Zuddas, P., \& Censi, P. (2012). Influence of $\mathrm{pH}$ and temperature on the early stage of mica alteration. Applied Geochemistry, 27(9), 1738-1744. doi:https://doi.org/10.1016/j.apgeochem.2012.02.009

Passchier, C. W., \& Trouw, R. A. J. (2005). Microtectonics (2nd ed.). Berlin Heidelberg New York: Springer.

Paukert, A. N., Matter, J. M., Kelemen, P. B., Shock, E. L., \& Havig, J. R. (2012). Reaction path modeling of enhanced in situ $\mathrm{CO} 2$ mineralization for carbon sequestration in the peridotite of the Samail Ophiolite, Sultanate of Oman. Chemical Geology, 330-331, 86-100. doi:https://doi.org/10.1016/j.chemgeo.2012.08.013

Peuble, S., Andreani, M., Godard, M., Gouze, P., Barou, F., Van de Moortele, B., .. . Reynard, B. (2015). Carbonate mineralization in percolated olivine aggregates: Linking effects of crystallographic orientation and fluid flow. American Mineralogist, 100(2-3), 474-482. doi:10.2138/am-2015-4913

Peuble, S., Andreani, M., Gouze, P., Pollet-Villard, M., Reynard, B., \& Van de Moortele, B. (2018). Multi-scale characterization of the incipient carbonation of peridotite. Chemical Geology, 476(Supplement C), 150-160. doi:https://doi.org/10.1016/j.chemgeo.2017.11.013

Plümper, O., Røyne, A., Magrasó, A., \& Jamtveit, B. (2012). The interface-scale mechanism of reaction-induced fracturing during serpentinization. Geology, 40(12), 1103-1106. doi:10.1130/G33390.1

Qiu, T., \& Zhu, Y. (2018). Listwaenite in the Sartohay ophiolitic mélange (Xinjiang, China): A genetic model based on petrology, U-Pb chronology and trace element geochemistry. Lithos, 302-303, 427-446. doi:10.1016/j.lithos.2018.01.029

Rai, D., Sass, B. M., \& Moore, D. A. (1987). Chromium(III) hydrolysis constants and solubility of chromium(III) hydroxide. Inorganic Chemistry, 26(3), 345-349. doi:10.1021/ic00250a002

Rajendran, S., Nasir, S., Kusky, T. M., Ghulam, A., Gabr, S., \& El-Ghali, M. A. K. (2013). Detection of hydrothermal mineralized zones associated with listwaenites in Central Oman using ASTER data. Ore Geology Reviews, 53, 470-488. doi:https://doi.org/10.1016/j.oregeorev.2013.02.008

Rioux, M., Bowring, S., Kelemen, P., Gordon, S., Miller, R., \& Dudás, F. (2013). Tectonic development of the Samail ophiolite: High-precision $\mathrm{U}-\mathrm{Pb}$ zircon geochronology and $\mathrm{Sm}-\mathrm{Nd}$ isotopic constraints on crustal growth and emplacement. Journal of Geophysical Research: Solid Earth, 118(5), 2085-2101. doi:10.1002/jgrb.50139

Rudge, J. F., Kelemen, P. B., \& Spiegelman, M. (2010). A simple model of reaction-induced cracking applied to serpentinization and carbonation of peridotite. Earth and Planetary Science Letters, 291(1), 215-227. doi:https://doi.org/10.1016/j.eps1.2010.01.016

Saddiqi, O., Michard, A., Goffe, B., Poupeau, G. r., \& Oberhänsli, R. (2006). Fission-track thermochronology of the Oman Mountains continental windows, and current 
problems of tectonic interpretation. Bulletin de la Société Géologique de France, 177(3), 127-134. doi:10.2113/gssgfbull.177.3.127

Scharf, A., Mattern, F., Bolhar, R., Bailey, C. M., Ring, U. (2020). U-Pb dating of postobductional carbonate veins in listwaenite of the Oman Mountains near Fanja. . Proceedings of the International Conference on Ophiolites and Oceanic Lithosphere, 12-14th January, 2020, Sultan Qaboos University, Muscat, Sultanate of Oman, page 220.

Scharf, A., Mattern, F., Moraetis, D., Callegari, I., \& Weidle, C. (2019). Postobductional Kinematic Evolution and Geomorphology of a Major Regional Structure-The Semail Gap Fault Zone (Oman Mountains). Tectonics, 38(8), 2756-2778. doi:10.1029/2019TC005588

Searle, M., \& Cox, J. (1999). Tectonic setting, origin, and obduction of the Oman ophiolite. GSA Bulletin, 111(1), 104-122. doi:10.1130/00167606(1999)111<0104:TSOAOO>2.3.CO;2

Searle, M. P., Waters, D. J., Martin, H. N., \& Rex, D. C. (1994). Structure and metamorphism of blueschist-eclogite facies rocks from the northeastern Oman Mountains. Journal of the Geological Society, 151(3), 555. doi:10.1144/gsjgs.151.3.0555

Soret, M., Agard, P., Dubacq, B., Plunder, A., \& Yamato, P. (2017). Petrological evidence for stepwise accretion of metamorphic soles during subduction infancy (Semail ophiolite, Oman and UAE). Journal of Metamorphic Geology, 35(9), 1051-1080. doi:10.1111/jmg.12267

Soret, M., Bonnet, G., Larson, K., Agard, P., Cottle, J., Dubacq, B., Button, M. Slow subduction initiation forces fast ophiolite formation. Proceedings of the International Conference on Ophiolites and the Oceanic Lithosphere: Results of the Oman Drilling Project and Related Research 12-14th January, 2020, Sultan Qaboos University, Muscat, Sultanate of Oman, page 234.

Stanger, G. (1985). Silicified serpentinite in the Semail nappe of Oman. Lithos, 18, 13-22. doi:https://doi.org/10.1016/0024-4937(85)90003-9

Streit, E., Kelemen, P., \& Eiler, J. (2012). Coexisting serpentine and quartz from carbonatebearing serpentinized peridotite in the Samail Ophiolite, Oman. Contributions to Mineralogy and Petrology, 164(5), 821-837. doi:10.1007/s00410-012-0775-z

Tutolo, B. M., Mildner, D. F. R., Gagnon, C. V. L., Saar, M. O., \& Seyfried, W. E., Jr. (2016). Nanoscale constraints on porosity generation and fluid flow during serpentinization. Geology, 44(2), 103-106. doi:10.1130/G37349.1

Ulven, O. I., Storheim, H., Austrheim, H., \& Malthe-Sørenssen, A. (2014). Fracture initiation during volume increasing reactions in rocks and applications for $\mathrm{CO} 2$ sequestration. Earth and Planetary Science Letters, 389, 132-142. doi:10.1016/j.eps1.2013.12.039

van Noort, R., Wolterbeek, T. K. T., Drury, M. R., Kandianis, M. T., \& Spiers, C. J. (2017). The force of crystallization and fracture propagation during in-situ carbonation of peridotite. Minerals, 7(10). doi:10.3390/min7100190 
Villey. M., Le Métour J. \& de Gramont, X. (1986). Geological Map of Fanjah. Bureau de Recherches Géologiques et Minières (BRGM), Orléans, France; Muscat, Oman, Ministry of Petroleum and Minerals, Directorate General of Minerals, Sultanate of Oman.

Virgo, S., Arndt, M., Sobisch, Z., \& Urai, J. L. (2013). Development of fault and vein networks in a carbonate sequence near Hayl al-Shaz, Oman Mountains. GeoArabia, 18(2), 99-136.

Virgo, S., Heup, T., Urai, J. L., \& Berlageet. T, (2016). Virtual Petrography (ViP) - A virtual microscope for the geosciences. Geophysical Research Abstracts, 18, EGU201614669-1 http://meetingorganizer.copernicus.org/EGU2016/EGU2016-14669-1.pdf

Wilde, A., Simpson, L., \& Hanna, S. (2002) Preliminary study of Cenozoic hydrothermal alteration and platinum deposition in the Oman Ophiolite. Vol. 6. Journal of the Virtual Explorer 6 (pp. 7-13).

Xing, T., Zhu, W., Fusseis, F., \& Lisabeth, H. (2018). Generating porosity during olivine carbonation via dissolution channels and expansion cracks. Solid Earth, 9(4), 879896. doi:10.5194/se-9-879-2018Zheng, X., Cordonnier, B., Zhu, W., Renard, F., \& Jamtveit, B. (2018). Effects of Confinement on Reaction-Induced Fracturing During Hydration of Periclase. Geochemistry, geophysics, geosystems, 19(8), 2661-2672. doi:10.1029/2017GC007322

Zhu, W., Fusseis, F., Lisabeth, H., Xing, T., Xiao, X., De Andrade, V., \& Karato, S.-i. (2016). Experimental evidence of reaction-induced fracturing during olivine carbonation. Geophysical Research Letters, 43(18), 9535-9543. doi:10.1002/2016GL070834 
Supplementary Table S1: Overview of studied thin sections of samples with cataclastic structures in Oman Drilling Project Hole BT1B

\begin{tabular}{|c|c|c|c|c|}
\hline $\begin{array}{l}\text { Sample ID } \\
\text { (exp. 5057_4B) }\end{array}$ & Lithology comment & Depth (m) & ViP & SEM \\
\hline BT1B_7-2_76-79 & localized cataclasite in red listvenite *\# & 7.66 & $\mathrm{x}$ & $\mathrm{x}$ \\
\hline BT1B_8-2_2-4 & $\begin{array}{l}\text { dolomite-cemented listvenite breccia with } \\
\text { cataclasite fragments*\# }\end{array}$ & 9.57 & & \\
\hline BT1B_9-3_28-31 & grey cataclastic listvenite *\# & 13.70 & $\mathrm{x}$ & $\mathrm{x}$ \\
\hline BT1B_11-2_31-34 & localized cataclasite in grey listvenite *\# & 17.53 & & \\
\hline BT1B_13-3_62-64 & localized cataclasite in listvenite ${ }^{*}$ & 23.46 & $\mathrm{x}$ & $\mathrm{x}$ \\
\hline BT1B_17-2_55-60 & red cataclastic listvenite and sharp fault * & 31.38 & $\mathrm{x}$ & $\mathrm{x}$ \\
\hline BT1B_18-2_60-63 & localized cataclasite in red listvenite *\# & 34.67 & & \\
\hline BT1B_18-3_16-19 & localized cataclasite in orange listvenite *\# & 35.22 & $\mathrm{x}$ & $\mathrm{x}$ \\
\hline BT1B_40-3_4-7 & localized cataclasite in ophicarbonate & 86.97 & $\mathrm{x}$ & \\
\hline BT1B_48-1_32-37 & localized cataclasite in veined listvenite \# & 109.67 & $\mathrm{x}$ & \\
\hline BT1B_51-4_20-25 & localized cataclasite in veined listvenite ${ }^{\#}$ & 118.08 & & \\
\hline BT1B_53-2_19-24 & localized $\mu \mathrm{m}$-scale cataclasite in listvenite & 122.34 & & \\
\hline BT1B_53-3_17-22 & localized $\mu \mathrm{m}$-scale cataclasites in listvenite \# & 123.10 & & \\
\hline BT1B_54-2_27-32 & localized $\mu \mathrm{m}$-scale cataclasites in listvenite $\#$ & 125.69 & & \\
\hline BT1B_54-3_42-47 & localized cataclasite in listvenite \# & 126.62 & & \\
\hline BT1B_58-3_20-25 & Localized cataclasite in listvenite *\# & 135.68 & & \\
\hline BT1B_63-3_61-66 & localized cataclasite in fuchsite-rich listvenite & 151.43 & $\mathrm{x}$ & \\
\hline BT1B_65-2_22-26 & localized cataclasite in grey listvenite ${ }^{*}$ & 156.17 & $\mathrm{x}$ & $\mathrm{x}$ \\
\hline BT1B_66-2_11-16 & cataclastic listvenite in listvenite *\# & 159.14 & $\mathrm{x}$ & \\
\hline BT1B_66-2_78-83 & localized cataclasite in listvenite \# & 159.81 & $\mathrm{x}$ & \\
\hline BT1B_67-2_36-40 & dolomite-cemented breccia in fuchsite-listvenite & 162.11 & $\mathrm{x}$ & $\mathrm{x}$ \\
\hline BT1B_70-3_55-60 & localized cataclasite in grey massive listvenite *\# & 172.25 & & \\
\hline BT1B_71-2_21-26 & white-green cataclasite in foliated listvenite *\# & 174.27 & $\mathrm{x}$ & \\
\hline BT1B_75-3_36-41 & cataclastic listvenite with dark matrix ${ }^{*}$ & 187.40 & & \\
\hline BT1B_76-1_42-48 & grey cataclastic listvenite *\# & 188.87 & & \\
\hline BT1B_78-2_34-38 & $\begin{array}{l}\text { localized } \mu \mathrm{m} \text {-scale cataclasite cutting foliated } \\
\text { dolomite listvenite }\end{array}$ & 195.87 & $\mathrm{x}$ & $\mathrm{x}$ \\
\hline BT1B_100-2_32-35 & cataclastic metamorphic sole & 244.62 & $x$ & $\mathrm{x}$ \\
\hline
\end{tabular}

Microstructural evidence for cataclasis post-dating listvenite formation in thin sections:

* cataclasite contains clearly identifiable rotated clasts of listvenite and vein fragments

\# cataclasite truncates veins that otherwise crosscut listvenite 